\title{
Mutual Fund Performance and Stock Market Anomalies*
}

\author{
Changha Kim, Ph.D. Candidate, KAIST \\ Jaeram Lee, Professor, Gachon University \\ Changjun Lee ${ }^{* *}$, Professor, Hankuk University of Foreign Studies
}

\begin{abstract}
To understand the underperformance of actively managed equity funds in Korean markets, we examine whether fund managers hold relatively over-priced stocks. To this end, we combine the information associated with 10 well-known anomalies to construct the implied mispricing measure for each stock and define it as the stock's A-score. On a fund level, we then construct the value-weighted average of the A-score decile ranks of individual stocks and define it as the investing measure. A fund with a high (low) investing measure means that it holds relatively undervalued (overvalued) stocks. Our empirical findings are as follows. First, on average, active funds do not hold undervalued stocks compared to benchmarks. Second, despite the underperformance of active funds, a subset of such funds persistently holds undervalued stocks. Third, our investing measure has a strong forecasting power regarding future performance. Funds with the highest $20 \%$ of the investing measure outperform those with the lowest $20 \%$ by an annualized four-factor alpha of $3.24 \%$, which is statistically significant. Overall, our results suggest that the performance of active funds may be improved by exploiting stock market anomalies.
\end{abstract}

Keywords: Active Fund; Anomaly; Factor Investing; Mispricing; Market Efficiency

JEL Classification: G11, G12

\footnotetext{
* The authors thank the two anonymous referees for their valuable comments. This work was supported by IREC, The Institute of Finance and Banking, Seoul National University. Changjun Lee is grateful for the Hankuk University of Foreign Studies Research Fund.

** Corresponding Author. Address: College of Business, Hankuk University of Foreign Studies 107, Imun-ro, Dongdaemoon-Gu, Seoul, Korea 02450; E-mail: leechangjun@hufs.ac.kr; Tel: +82-2-2173-8812; Fax: +82-2-2173-3558.
}

Received: March 11, 2019; Revised: November 12, 2019 \& December 18, 2019; Accepted: December 23, 2019 


\title{
액티브펀드의 성과와 주식시장의 이상현상
}

\author{
김 창 하 (KAIST 박사과정) \\ 이 재 람 (가천대학교 교수) \\ 이 창 준 (한국외국어대학교 교수)**
}

\begin{abstract}
본 연구에서는 주식시장에서 보고된 이상현상에 기반하여 국내 주식형펀드의 저성과 원인을 분석 하였다. 이를 위해, 첫째, 주식 수익률의 차이를 야기하는 10 개 변수를 통해 개별 주식의 저평가 또는 고평가 여부를 측정하였으며 이를 A-Score로 정의하였다. 둘째, 펀드가 보유하고 있는 주식들의 AScore를 이용하여 개별 펀드의 지표를 정의하였으며 이를 펀드의 Investing measure로 정의하였다. Investing measure가 높은(낮은) 펀드는 상대적으로 저평가(고평가)된 주식을 많이 보유하고 있음을 의미한다. 본 연구의 실증분석 결과는 다음과 같다. 첫째, 전체적으로 액티브펀드는 벤치마크에 비해 저평가된 주식을 보유하고 있지 않으며 이는 액티브펀드의 우월하지 못한 성과와 관련이 있는 것으로 해석된다. 둘째, 그럼에도 불구하고 일부의 액티브펀드는 벤치마크에 비해 지속적으로 저평가된 종목을 보유하고 있으며 상대적으로 우수한 성과를 달성하고 있음이 확인되었다. 셋째, Investing measure는 미래 액티브펀드의 성과에 대한 예측력을 보유하는 지표임을 확인하였다. Investing measure가 가장 높은 20\%의 펀드 그룹은 그 지표가 가장 낮은 그룹에 비해 CAPM 알파는 월 $0.33 \%$ (연 $3.96 \%$ ), 그리고 4요인 알파는 월 $0.27 \%$ (연 3.24\%) 높게 추정되었으며 이는 통계적으로 유의하다. 본 연구의 결과는 주식시장의 이상현상을 활용한 투자전략을 구사할 경우 액티브펀드의 성과가 개선될 수 있음을 시사 한다.
\end{abstract}

핵심 단어 : 액티브펀드, 이상현상, 팩터투자, 가격오류, 시장효율성

JEL 분류기호: G11, G12

* 본 논문에 유익한 논평을 해 주신 두 분의 심사위원님께 감사드립니다. 본 논문은 서울대학교 증권·금융연구소 투자연구교육센터의 지원을 받아 연구되었습니다. 이창준 교수는 한국외국어 대학교 교내학술연구비의 지원을 받았음을 밝혀 둡니다.

** 연락담당 저자. 주소: 서울특별시 동대문구 이문로 107 한국외국어대학교 경영대학, 02450; E-mail: leechangjun@hufs.ac.kr; Tel: 02-2173-8812; Fax: 02-2173-3558. 


\section{1. 서론}

주식형 펀드의 성과 및 성과지속성에 대한 연구는 재무학에서 가장 중요한 연구주제 중의 하나이다. 학문적으로는 시장효율성의 성립 여부에 대한 증거를 제시할 수 있으며, 실무 적으로는 그 규모가 확대되고 있는 자산운용업의 정당성에 대한 증거를 제시할 수 있기 때문이다. 이러한 이유 때문에, Jensen(1968)의 연구를 시작으로 해외 및 국내시장에서 주식형 펀드의 성과에 대한 연구가 매우 활발하게 전개되었는데 미국시장의 연구들은 대부분 주식형 펀드의 성과가 벤치마크에 비해 우월하지 못함을 보고하고 있다(Grinblatt and Titman, 1989; Wermers, 2000; Kacperczyk et al., 2005; French, 2008; Cremers and Petajisto, 2009; Busse et al., 2013). 마찬가지로, 국내시장의 최근 연구결과들도 주식형 펀드의 저성과를 보고하고 있다(Yoo and Kim, 2012; Ha, 2014). 선행연구들은 일반적으로 이러한 주식형 펀드의 저성과를 주식시장의 효율성을 보여주는 증거의 하나로 해석하고 있다. 그러나 펀드 매니저들은 대체로 일반 투자자들에 비해 상대적으로 높은 전문성과 정보 우위를 보유하고 있을 것으로 평가된다. 따라서 펀드 매니저가 운용하는 주식형 펀드들이 초과 성과를 달성하지 못하는 현상을 단순히 시장 효율성으로 해석하는 것은 여전히 의문의 여지가 있으며 이에 대한 심층적인 분석이 필요하다.

주식형 펀드의 저성과 현상을 이해하는 또 다른 방법은 주식시장에서 발견되고 있는 이상 현상(anomaly)을 이용하여 펀드의 성과를 분석하는 것이다. 이상현상은 시가총액, 장부가치 대 시장가치 비율, 과거수익률, 변동성, 수익성 등의 기업 특성변수들을 활용해 포트폴리오를 구성하였을 때 장기적으로 포트폴리오 사이에 유의미한 수익률 차이가 발생하는 것을 의미한다. 따라서 이상현상을 야기하는 기업의 특성변수들을 활용하여 펀드 매니저의 보유종목을 분석 한다면 펀드의 성과 원천을 이해할 수 있다. 다시 말해, 이상현상을 야기하는 특성변수들은 개별 주식의 저평가 혹은 고평가에 대한 일종의 신호로 해석할 수 있으며, 주식형 펀드의 저성과는 이상현상을 고려했을 때 상대적으로 고평가된 주식을 보유했기 때문에 발생할 수 있다.

실제로 미국시장에서는 최근 이러한 방식으로 주식형 펀드의 성과를 분석하는 연구가 진행되고 있다. 예를 들어, Ali et al.(2008, 2014)은 미국시장에서 펀드 매니저들이 발생액 이상현상(accrual anomaly) 및 이익발표 후 잔류현상(post earnings announcement drift)에 기반한 투자전략을 구사하고 있는지 살펴보았다. Edelen et al.(2016) 역시 기관 투자자들이 이상현상에 의해 고평가된 것으로 판정하는 주식들을 매수하는 경향이 있음을 지적했다. 국내 시장에서도 주식형 펀드의 성과에 대한 연구가 활발하게 전개되고 있는 것은 사실이지만, 이와 같이 주식시장의 이상현상을 이용하여 주식형 펀드의 성과에 대한 이해를 시도하는 연구는 드물다.

이에 본 연구는 국내 주식형 펀드들의 저성과 원인이 이상현상을 고려할 때 상대적으로 고평가된 주식들을 보유했기 때문임을 규명하고자 한다. 주식형 펀드는 결국 개별 주식들로 
구성된 포트폴리오라는 측면에서 국내 주식형 펀드의 성과를 개별 종목의 저평가 또는 고평가 측면에서 살펴보는 본 연구는 액티브펀드의 성과에 대한 이해에 큰 도움이 될 것이다. 또한 이상현상은 시장마다 다르게 나타날 수 있으므로 이러한 관점에서 분석이 이루어지기 위해서는 특히 국내 주식시장의 이상현상들을 중점적으로 고려해야 한다. 때마침 국내시장에서도 서로 다른 수익률을 야기할 수 있는 새로운 기업 특성변수들이 활발하게 보고되고 있으므로 (Ko and Kim, 2009, 2014; Kim et al., 2018; Yoon et al., 2017), 본 연구는 시의적으로 적절한 기여를 할 수 있을 것으로 기대한다.

이와 같은 방식으로 주식형 펀드의 성과를 이해하기 위해서는 이상현상들이 개별 주식들의 저평가 또는 고평가 여부에 대해 충분한 정보를 제공해야 한다. 이를 위해서는 주식시장에서 발생하는 이상현상들이 최소한 부분적으로는 위험 프리미엄이 아니라 가격오류(mispricing) 때문에 발생한다는 가정이 필요하다. 최근의 연구들이(Stambaugh et al., 2012; Stambaugh and Yuan, 2016) 이상현상의 일부가 가격오류로 인해 발생함을 지지한다는 사실을 고려할 때 이러한 가정은 비현실적이라고 보기는 어렵다. 문제는 특정한 이상현상에 의존하여 저평가 또는 고평가 여부를 판단하는 것은 매우 위험하다는 것이다. 이상현상을 야기하는 특성변수 들은 평균적으로 저평가 혹은 고평가되어 있는 주식들을 분리할 뿐이며 이 기준은 완전하다고 보기 어렵다. 즉, 개별 이상현상들은 주식의 저평가 여부에 대한 잡음(noise)이 포함된 신호로 볼 수 있다. 또 서로 다른 이상현상들이 동일한 주식에 대해 일관되지 않는 판정을 내릴 수도 있다.

이러한 약점을 극복하기 위해서 본 연구에서는 국내 주식시장에서 보고된 여러 이상현상을 종합적으로 고려하여 저평가 또는 고평가의 여부를 판단한다. 잡음이 존재하는 신호의 신뢰성을 높이는 가장 일반적인 방법은 독립적인 다수의 신호들을 취합하는 것이기 때문이다. 즉, 성격이 상이한 다수의 이상현상에 대해 저평가 여부를 취합하여 개별 주식들의 저평가 여부에 대해 보다 정확한 판단을 내릴 수 있다. 뿐만 아니라 펀드를 운용하는 펀드 매니저들 입장 에서도 하나의 기업특성을 고려하여 종목을 선택할 가능성은 상대적으로 낮다. Stambaugh and Yuan(2016)은 실제로 미국 주식시장에 대해 여러 이상현상들을 취합한 통합 가격오류 측도(composite mispricing measure)을 구축하였으며, Jeon et al.(2017)은 이를 미국 주식형 펀드 평가에 적용하였다.

구체적으로 본 연구의 방법론을 설명하자면, 첫째, 국내의 선행연구를 바탕으로 주식 수익률의 차이를 야기하는 10 개 변수를 종합하여 개별 주식의 저평가 또는 고평가의 여부를 측정하고 이를 A-Score로 정의하였다. 본 연구에서는 A-Score가 높을수록 상대적으로 저평가된 주식이라 가정한다. 둘째, 펀드가 보유하고 있는 주식들의 A-Score를 이용하여 개별 펀드의 지표를 정의하였으며 이를 펀드의 Investing measure로 정의하였다. ${ }^{1)}$ Investing measure가 높은(낮은) 펀드는 상대적으로 저평가(고평가)된 주식을 많이 보유하고 있음을 의미한다.

1) 본 연구에서는 Jeon et al.(2017)이 미국 주식형 펀드의 연구에서 정의한 A-Score와 Investing measure를 국내시장에 적용하였다. 
한국증권학회지 제49권 1호 (2020)

본 연구의 주요 실증분석 결과는 다음과 같다.

첫째, 이상현상들을 취합한 A-Score가 개별 주식의 가격오류를 포착할 수 있음을 확인 하였다. A-Score가 가장 높은 $10 \%$ 의 주식을 매수하고 가장 낮은 $10 \%$ 주식을 매도하는 포트폴리오의 월 평균수익률은 2.77\%( $t$-값=6.69)로 추정되었으며, Carhart(1997) 4요인 알파도 월 2.46\%( $t$-값=6.74)로 추정된 점, 그리고 주식시장의 이상현상을 종합적으로 고려한 $\mathrm{A}-\mathrm{Score}$ 에 따른 주식의 수익률 차이가 개별 기업특성에 따른 수익률 차이보다 월등하게 크게 추정된 점이 이를 뒷받침한다. 한편, A-Score가 높은 주식일수록 시장베타와 변동성은 낮게 추정되었다. 다만, A-Score가 높은 주식은 소형주와 가치주로 드러났는데, 특히, A-Score가 가장 높은 $10 \%$ 주식의 시가총액은 매우 낮게 추정되었다. 뿐만 아니라 A-Score가 높은 주식들은 상대적으로 거래량과 유동성이 부족하였다. 이는 펀드 매니저가 주식의 이상현상에 기반하여 투자전략을 실행하기가 용이하지 않음을 의미한다. 왜냐하면, KOSPI 200 지수 또는 KOSPI 지수가 대부분 주식형 펀드의 벤치마크로 사용되고 있다는 측면을 고려하면 펀드 매니저는 상대적으로 이러한 주식에 대해 투자하기가 쉽지 않기 때문이다.

둘째, 전체적으로 액티브펀드는 벤치마크에 비해 저평가된 주식을 많이 보유하고 있지 않은 것으로 나타났다. 즉, 액티브펀드 전체의 Investing measure는 KOSPI 200 지수, KOSPI 지수, 그리고 패시브펀드의 Investing measure와 비교했을 때 일관되게 낮게 추정 되었다. Investing measure가 해당 종목의 저조한 수익률을 나타내는 지표임을 감안하면 이것이 액티브펀드의 우월하지 못한 성과와 관련이 있는 것으로 해석된다. 또한, 단일 기업 특성을 고려하여 펀드의 투자종목을 분석한 경우 벤치마크나 패시브펀드에 비해 액티브펀드가 특정 운용스타일에 편중된 현상은 관찰되지 않았으며, 이는 전반적으로 펀드매니저가 주식 시장의 개별 이상현상에 기반한 투자도 하고 있지 않음을 의미한다.

셋째, 그럼에도 불구하고 일부의 액티브펀드는 벤치마크에 비해 지속적으로 저평가된 종목을 보유하고 있으며 이들은 상대적으로 우수한 성과를 달성하고 있음이 확인되었다. Investing measure가 가장 높은 $20 \%$ 의 그룹(Q5)은 KOSPI에 비해 저평가된 주식의 보유 비중은 높으며 고평가된 주식의 보유비중은 낮은 것으로 추정되었으며, 이 그룹에 속한 펀드가 1 년 및 5 년 후에도 같은 그룹에 머무를 확률은 각각 $60 \%$ 와 $43 \%$ 로 측정되었다. 또한, 이 그룹(Q5)에 속한 펀드들은 상대적으로 우수한 성과를 달성하는 것으로 나타났는데, 비용 공제 이전 CAPM 알파는 월 $0.20 \%(t$-값 $=2.14)$ 로 추정되었다. 액티브펀드의 벤치마크가 대부분 KOSPI 지수나 KOSPI 200 지수라는 측면을 고려하면 Q5 그룹은 시장보다 우월한 성과를 달성하는 것으로 해석할 수 있다. 그러나, 4 요인 알파는 월 $0.08 \%(t-$ 값 $=0.90)$ 으로 추정되어 기업규모요인, 가치요인, 모멘텀요인을 통제한 초과수익률은 존재하지 않는 것으로 나타났다.

넷째, Investing measure는 미래 액티브펀드의 성과 차이를 설명할 수 있는 지표임을 확인하였다. Investing measure가 증가할수록 모든 성과지표들은 향상되었으며, 특히 Investing measure가 가장 높은 펀드 그룹은 그 지표가 가장 낮은 그룹에 비해 CAPM 
알파는 월 0.33\%(연 3.96\%), 그리고 4요인 알파는 월 0.27\%(연 3.24\%) 높게 추정되었으며 이는 통계적으로 유의하다. 한편, 펀드의 수익률을 예측한다고 알려진 변수들을 통제하여 실시한 회귀분석에서도 펀드의 미래 성과에 대한 Investing measure의 회귀계수는 일관되게 양으로 유의하게 추정되었다. 이는 상대적으로 저평가된 주식에 투자하는 펀드일수록 향후 수익률이 높음을 의미하므로 Investing measure는 액티브펀드의 성과향상에 기여하는 지표임이 확인되었다.

대부분의 선행연구들은 펀드의 저성과 원인을 종목선택능력과 마켓타이밍능력으로 분석 하였는데, 본 연구는 액티브펀드 매니저가 종목선택능력을 보유하기 어려운 이유를 주식 시장의 이상현상을 통해 구체적으로 분석했다는 점에서 선행연구와 차별성을 갖는다. 본 연구의 결과는 평균적으로 국내 액티브펀드 매니저들이 다양한 이상현상에 기반한 팩터 (factor) 투자전략을 구사하지 않는다는 사실을 보여준다. 학문적으로는 미국 주식시장에 비해 상대적으로 국내 주식시장에서 이상현상에 대한 연구가 부족하여 아직까지 팩터 투자 전략의 유용성에 대해 잘 정립된 연구결과가 부족하다는 측면과 관련되어 있다. 또한, 실무 적으로는 단기간의 성과에 따라 평가받는 경력위험(career risk)을 지닌 펀드매니저가 벤치 마크와 괴리가 있는 포트폴리오를 장기간 보유하여 초과성과를 달성하는 전략을 구사하기가 용이하지 않은 측면도 고려할 수 있다.

그럼에도 불구하고, 일부 액티브펀드는 벤치마크에 비해 지속적으로 저평가된 종목을 보유함으로써 상대적으로 우수한 성과를 달성하고 있음을 확인하였다. 즉, 미래 펀드 수익률에 대해서 Investing measure가 유의미한 예측력을 가지고 있었다. 이는 주식형 펀드의 수익률을 향상시키기 위해 이상현상을 활용한 투자전략을 구사할 필요가 있음을 보여준다. 다만 일반 적으로 펀드 매니저들은 특정 펀드를 운용함에 있어 일정 비중이상의 벤치마크 종목 편입 의무, 추적오차 한도 등과 같은 제약을 받으며, 이상현상에 의해 저평가되어 있는 것으로 판단되는 주식들은 대체로 소형주이거나 유동성이 낮아 이러한 투자제약에 의해 보유가 어려울 여지가 크다. 본 연구의 결과는 펀드매니저가 당면한 제약이 액티브펀드의 성과에 부정적인 영향을 미쳤을 가능성이 있음을 시사한다.

이후 논문의 구성은 다음과 같다. 우선, 제 2장에서는 관련문헌연구를 통해 본 연구가 가지는 차별성을 살펴본다. 제 3장에서는 연구의 자료 및 방법론을 제시하며 제 4 장에서는 실증분석 결과를 보고한다. 마지막으로 제 5 장에서는 본 연구의 결론과 한계점을 제시한다.

\section{2. 관련문헌연구 및 시사점}

관련문헌은 주식시장의 이상현상에 대한 연구와 주식시장에서 보고된 이상현상을 이용한 주식형 펀드의 분석에 대한 연구로 분류할 수 있다. 주식시장의 이상현상에 대한 연구가 매우 활발하게 진행되고 있는 미국시장에서는 이상현상을 이용한 주식형 펀드의 성과분석에 대한 연구도 최근 활발히 전개되고 있지만, 국내시장에서는 이상현상에 대한 연구가 주식 
한국증권학회지 제49권 1호 (2020)

시장에 국한되어왔다. 본 장에서는 해외 및 국내시장의 관련문헌을 통해 시사점을 도출하고 이를 바탕으로 본 연구가 갖는 차별성을 살펴본다.

\section{1 미국시장에 대한 연구}

\subsection{1 주식시장의 이상현상에 관한 연구}

$\operatorname{Banz}(1981)$ 는 소형주의 수익률이 대형주의 수익률보다 높은 기업규모효과(size effect)를 보고하였으며, Stattman(1980)과 Rosenberg et al.(1985)은 장부가치 대 시장가치 비율이 높은 가치주의 수익률이 그 비율이 낮은 성장률의 수익률보다 높은 가치효과(value effect)를 발견하였다. 그리고 Jegadeesh and Titman(1993)은 과거 몇 달 동안 수익률이 높은 주식이 향후 몇 달 동안에도 높은 수익률을 보인다는 모멘텀효과(momentum effect)를 보고하였다. 이들은 주식시장에서 알려진 가장 전통적인 이상현상이며 주식형 펀드의 운용스타일 전략으로 널리 사용되고 있다.

한편, 최근에는 주식시장에서 다양한 이상현상이 보고되고 있는데 관련 연구를 요약하면 다음과 같다. 첫째, 기업의 투자와 관련된 이상현상이 보고되고 있는데, Titman et al.(2004)는 비정상적인 자본투자(abnormal capital investment)가 높을수록 향후 주식 수익률이 낮아 짐을 보고하였으며, Cooper et al.(2008)은 총자산의 증가율(asset growth)이 높을수록 향후 수익률이 낮음을 보고하였다. 둘째, 발생액과 관련된 이상현상이 보고되었는데, Sloan(1996)은 기업규모 대비 발생액의 크기가 낮았던 기업의 미래 수익률이 상대적으로 높은 현상을 발견 하였다. 셋째, 기업의 수익성과 관련된 이상현상이 보고되었다. 예를 들어, Fama and French (2006)는 장부가치 대 시장가치 비율이 유사한 기업의 경우에 총자산수익률(ROA) 또는 자기자본수익률(ROE)이 높은 기업의 수익률이 우월함을 보고하였으며, Novy-Marx(2013)는 자산대비 총수익(gross profits-to-assets)이 기업의 이익을 측정하는 더 좋은 측정치임을 주장하며 이 비율이 높을수록 향후 수익률이 높음을 보고하였다. 마지막으로, 기업의 변동성과 관련된 이상현상도 보고되었는데, Ang et al.(2006)은 비체계적 위험이 상대적으로 높은 기업의 향후 수익률이 상대적으로 낮은 저변동성 효과를 발견하였다.

\subsection{2 이상현상을 이용한 주식형 펀드에 대한 연구}

Grinblatt et al.(1995)는 미국 시장에서 펀드 매니저가 모멘텀 전략을 구사하고 있는지 살펴보았는데 연구에 의하면, 약 $77 \%$ 의 펀드 매니저가 모멘텀 전략을 실행하고 있으며 이 전략을 구사하는 펀드의 수익률이 그렇지 않은 펀드에 비해 우월함을 보고하였다. Chan et al.(2002)은 주식형 펀드의 운용스타일이 벤치마크인 S\&P500 지수와 큰 차이를 보이지 않았지만, 상대적으로 성장주와 과거승자주(past winner)에 투자하는 경향을 발견 하였다.

주식시장에서 다양한 이상현상이 보고됨에 따라 최근에는 이를 이용한 펀드 시장의 분석도 활발하게 진행되고 있다. Ali et al.(2008)는 펀드 매니저들이 Sloan(1996)에 의해 알려진 
발생액 이상현상에 기반한 투자를 하고 있는지 살펴보았는데, 발생액 이상현상에 기반한 투자전략이 유의한 양의 초과 수익률을 창출함에도 불구하고 전반적으로 이 현상을 이용한 투 자전략을 구사하고 있지 않음을 발견하였다. Tice and Zhou(2011)는 Piotroski(2000)가 개발한 F-score를 이용하여 펀더멘탈이 강한 주식과 그렇지 않은 주식을 나눈 후 펀드 매니저의 투자행위를 살펴보았다. 연구에 의하면, 펀드 매니저는 평균적으로 펀더멘탈이 강한 기업에 투자하지 않는 것으로 나타났으며 그들은 펀드 매니저의 이러한 행위가 주식 시장의 이상현상이 지속되는 것과 관련이 있음을 주장하였다. Ali et al.(2014)은 펀드 매니저 들이 이익발표 후 잔류현상(post earnings announcement drift)에 기반한 투자전략을 구사 하고 있지만 펀드 매니저들의 경쟁으로 인해 수익성은 높지 않음을 보고하였다. Chen(2015)과 Akbas et al.(2015)는 주식형 펀드로의 순유입이 주식시장의 가격오류(mispricing)를 악화 시키고 있음을 보고하였다.

한편, Jeon et al.(2017)은 주식시장에서 제기된 15개의 이상현상을 종합적으로 고려하여 주식형 펀드의 운용스타일을 파악하였다. 이들은 개별 주식에 대하여 15 개의 이상현상을 종합적으로 고려한 후 해당 주식의 고평가 또는 저평가 유무를 결정하였으며 이를 펀드로 적용하여 펀드가 상대적으로 저평가된 주식에 투자하는지를 살펴보았다. 연구에 의하면, 미국 주식형 펀드는 벤치마크에 비해 상대적으로 고평가된 주식에 많이 투자하고 있는 것으로 나타났으며, 이는 미국 주식형 펀드가 평균적으로 벤치마크에 비해 저조한 성과를 달성하고 있는 것과 일치함을 주장하였다.

\section{2 국내시장에 대한 연구}

국내 주식시장에서도 전통적인 이상현상에 대한 연구는 활발하게 전개되었는데 선행연구를 종합하면 다음과 같다. 첫째, 기업규모효과는 존재하지만(Ko and Kim, 2007; Yun et al., 2009), 2000년 이후의 자료에서는 존재하지 않음이 보고되고 있다(Eom, 2013; Lee and Jang, 2015). 둘째, 가치효과에 대한 실증분석결과는 혼재되어 있지만, 미국 시장에 비해 가치효과가 약하게 나타나고 있음이 보고되고 있다(Kim, 2004; Ko and Kim, 2007). 셋째, 모멘텀효과는 2000년 이후에 특히 강하게 나타남이 발견되고 있다(Eom, 2013; Lee and Jang, 2015).

또한, 전통적인 이상현상 뿐만 아니라 해외시장에서 제기된 새로운 이상현상에 대한 연구도 이루어지고 있다. Yun et al.(2009)은 국내 주식시장에서 주식거래회전율(turnover)은 주식 수익률과 유의한 음의 관계가 있음을 보고하였다. Ko and $\operatorname{Kim}(2009)$ 은 국내 주식시장에서 발생액 이상현상이 강하게 나타남을 보고하였으며 주로 차익거래위험이 높은 주식에서 이 현상이 집중됨을 보고하였다. Ko and $\operatorname{Kim}(2014)$ 은 장기적으로 고유변동성이 낮은 주식의 수익률이 높은 주식의 수익률보다 높음을 보고하였으며 이 현상은 2000년 이후의 기간에서만 유의하게 나타남을 발견하였다. Kim et al.(2018)은 국내 주식시장에서 수익성 프리미엄이 강하게 나타남을 발견하였으며 이는 정보 불확실성 및 차익거래의 제한과 관련 있음을 보고 
한국증권학회지 제49권 1호 (2020)

하였다. 한편, Yoon et al.(2017)은 11개의 이상현상을 고려하여 다양한 비중결정방식에 따라 최적화된 포트폴리오의 성과를 측정하였다. 연구에 의하면, 시가총액비중방식 이외의 방식으로 최적화된 포트폴리오를 구성하는 경우와 시장전체 종목이 아닌 이상현상이 관측되는 종목만을 대상으로 투자전략을 구사하는 경우에는 유의한 초과수익률이 달성됨을 보였다.

한편, 국내시장에서도 주식형 펀드에 대한 연구는 매우 활발하게 진행되었는데 대부분의 연구는 펀드의 성과 및 성과지속성에 대해서 살펴보았다. ${ }^{2)}$ 본 연구에서는 액티브펀드의 성과가 우월하지 못한 이유를 주식시장의 이상현상과 관련 지어 살펴보므로 본 절에서는 이와 관련된 선행연구를 살펴본다.

첫째, 국내 주식형 펀드시장에서도 이상현상과 관련된 연구가 존재하지만 대부분 전통 적인 이상현상에 대하여 살펴보았다. Lee and Jeon(2012)의 연구에 의하면, 국내 주식형 펀드의 대형주와 성장주 쏠림 현상이 KOSPI 200보다 상대적으로 심한 것으로 나타났다. Fama and French(1993)의 3요인에 기간스프레드와 부도스프레드를 추가한 5요인 모형을 이용한 Yoo and $\operatorname{Kim}(2012)$ 의 연구에 의하면, 국내 펀드는 상대적으로 가치주와 대형주에 투자하고 있는 것으로 나타났다. 둘째, 최근의 연구들은 액티브펀드의 저성과를 보고하고 있다. Yoo and $\operatorname{Kim}(2012)$ 은 2001년부터 2009년까지 국내 주식형 펀드는 KOSPI 지수에 비해 수익률이 연 평균 $0.13 \%$ 낮음을 보고하였으며, $\mathrm{Ha}(2014)$ 는 액티브펀드가 패시브펀드에 비해서 성과보수는 높지만 성과가 저조함을 보고하였다. 또한, Paek and $\mathrm{Ko}(2015)$ 는 펀드 매니저의 잦은 거래가 수익성의 악화와 관련 있음을 보고하였다.

\section{3 시사점}

지금까지의 선행연구를 종합하면 중요한 시사점이 도출된다. 이는, 국내 주식시장에서도 최근 해외시장에서 발견된 새로운 이상현상에 대한 연구가 활발하게 진행되고 있지만 국내 펀드시장에서 다양한 이상현상을 종합적으로 고려하여 액티브펀드의 성과를 살펴본 연구는 존재하지 않는다는 사실이다. 이상현상은 사후적으로는 이론적 근거에 의해 설명될 수 있으나, 개별 시장의 특성에 따라 크게 다르게 관찰되는 경향이 강하다. 즉, 특정 시장에서 나타난 이상현상이 다른 시장에서는 명확하게 나타나지 않을 수 있다. 따라서 미국 자본시장과 한국 자본시장에서 관찰되는 이상현상에는 차이가 있을 수 있다. 또한 과거에는 관찰되었던 이상현상이 점차 관찰되지 않을 수 있으며, 반대로 과거에는 관찰되지 않았던 이상현상이 새롭게 관찰되는 경우도 있다. 예컨대 Kim and Lee(2018)에 따르면 2000년 이전에는 국내 주식시장에서 모멘텀 현상이 잘 관찰되지 않았지만 2000년 이후에는 모멘텀 현상이 상대적으로 명확하게 나타나고 있다. 따라서 국내 주식형 펀드들의 저성과 현상을 설명하기 위해서는 Jeon et al.(2017)과 달리 한국 자본시장에 대해 가급적 최근 보고된 이상현상들에 집중하여 분석하는 것이 바람직하다고 할 것이다.

2) 국내 주식형 펀드에 대한 선행연구들은 $\mathrm{Ko}(2011)$ 의 제 4장에 매우 자세히 정리되어 있다. 
Mutual Fund Performance and Stock Market Anomalies

서로 다른 수익률을 가지는 기업의 특성변수들이 활발하게 보고되고 있는 측면, 그리고 주식형 펀드는 결국 주식으로 구성된 포트폴리오라는 측면에서 주식시장에서 발견된 이상 현상을 이용하여 액티브펀드의 운용스타일과 성과를 분석한다면 국내 액티브펀드의 성과 이해에 큰 도움이 될 것이다.

\section{3. 표본 자료 및 주요 변수}

\section{1 표본 자료}

본 연구에서는 국내주식형 펀드의 성과를 분석하기 위하여, FnGuide 펀드평가에서 제공하는 국내주식형 펀드의 월별 포트폴리오 자료와 일별 수익률 자료를 이용하였다. 월별 포트폴리오 자료는 2001년 7월부터 2017년 11월까지이며, 일별 수익률 자료는 2001년 1월부터 2017년 12월까지이다. 대유형이 국내주식형인 펀드들을 분석 대상으로 하며, 이 중

\section{〈표 1〉국내 액티브펀드의 성과}

이 표는 국내주식형 액티브펀드, 시장지수, 패시브펀드의 수익률 및 수익률 차이를 나타낸다. 펀드의 수익률은 매년 12 개월 간 존속한 개별 펀드들의 복리화 된 연간 수익률을 연초의 순자산액으로 가중 평균하여 계산하였다. 최소 10 개 이상의 개별 펀드들이 존재하는 경우에만 특정 해의 수익률을 계산하였다. 펀드의 수익률에 배당수익이 포함된다는 점을 고려하여, KOSPI와 KOSPI 200의 수익률도 배당을 포함한 전체수익률(total return)을 보고한다. 표의 마지막 두 행은 연간수익률을 산술 평균한 평균 수익률과 전체기간 동안 복리화 된 누적수익률을 각각 나타낸다.

\begin{tabular}{lrrrrrrr}
\hline & $(\mathrm{A})$ & $(\mathrm{B})$ & $(\mathrm{C})$ & \multicolumn{1}{c}{$(\mathrm{D})$} & \multicolumn{1}{c}{$(\mathrm{E})$} & \multicolumn{1}{c}{$(\mathrm{F})$} & \multicolumn{1}{c}{$(\mathrm{G})$} \\
\hline 연도 & 액티브펀드 & \multicolumn{1}{c}{ KOSPI } & $\begin{array}{c}\text { KOSPI } 200 \\
(\%)\end{array}$ & \multicolumn{1}{c}{ 패시브펀드 } & (A) $)(\mathrm{B})$ & $(\mathrm{A})-(\mathrm{C})$ & $(\mathrm{A})-(\mathrm{D})$ \\
\hline 2001 & 16.01 & 36.48 & 37.93 & & -20.47 & -21.92 & \\
2002 & 0.93 & -8.03 & -4.48 & & 8.96 & 5.41 & \\
2003 & 35.32 & 32.33 & 35.34 & 34.85 & 2.99 & -0.02 & 0.47 \\
2004 & 5.87 & 14.37 & 13.94 & 10.64 & -8.50 & -8.08 & -4.77 \\
2005 & 64.63 & 56.03 & 55.88 & 53.62 & 8.60 & 8.75 & 11.01 \\
2006 & 2.68 & 6.23 & 7.09 & 6.00 & -3.55 & -4.41 & -3.32 \\
2007 & 44.50 & 34.62 & 33.61 & 32.53 & 9.88 & 10.90 & 11.98 \\
2008 & -37.16 & -39.30 & -38.81 & -37.62 & 2.14 & 1.65 & 0.45 \\
2009 & 56.00 & 51.91 & 52.49 & 54.02 & 4.09 & 3.51 & 1.98 \\
2010 & 20.87 & 23.58 & 24.62 & 24.98 & -2.71 & -3.75 & -4.11 \\
2011 & -12.17 & -9.72 & -10.70 & -11.74 & -2.45 & -1.47 & -0.43 \\
2012 & 8.74 & 10.68 & 11.64 & 11.99 & -1.94 & -2.90 & -3.24 \\
2013 & 2.77 & 1.99 & 1.40 & 0.84 & 0.77 & 1.36 & 1.93 \\
2014 & -3.05 & -3.65 & -4.92 & -7.88 & 0.60 & 1.87 & 4.83 \\
2015 & 5.91 & 4.07 & 1.72 & -0.39 & 1.83 & 4.18 & 6.29 \\
2016 & -2.50 & 5.04 & 6.78 & 8.08 & -7.53 & -9.28 & -10.57 \\
2017 & 21.02 & 23.91 & 25.74 & 31.93 & -2.89 & -4.72 & -10.91 \\
\hline 평균 & 13.55 & 14.15 & 14.66 & 14.12 & -0.60 & -1.11 & 0.11 \\
누적수익률 & 477.41 & 542.51 & 591.82 & 404.26 & -13.79 & -21.43 & -1.54 \\
\hline
\end{tabular}


한국증권학회지 제49권 1호 (2020)

주된 분석 대상은 소유형이 액티브펀드 ${ }^{3)}$ 인 펀드들이다. 국내 액티브펀드 시장을 대표하는 펀드들을 선택하기 위하여 표본 기간 동안 평균 순자산액이 50억 원 이상인 펀드들만 고려 하였다. 또한 해지되기 직전의 펀드 수익률에는 인위적인 수익률 조작이 많다는 $\mathrm{Ko}(2014)$ 의 지적에 따라, 해지된 펀드의 해지 직전 6 개월 관측치는 분석에서 제외하였다. 그리고 적어도 6 개월 이상의 관측치가 있는 펀드들만 분석 대상에 포함하였다. 끝으로 실제로 운용이 이루어지는 포트폴리오 수준으로 펀드 수익률을 살펴보기 위하여, 자펀드와 종류형 펀드는 제외하고 모펀드와 일반펀드를 분석 대상에 포함하였다.

<표 1>은 표본 액티브펀드의 연도별 성과를 나타낸다. 비교를 위해서 KOSPI와 KOSPI 200의 배당을 포함한 수익률, 그리고 패시브펀드의 성과도 함께 보고하였다. ${ }^{4)}$ 전체 기간 동안 액티브펀드의 성과가 시장대표지수나 패시브펀드에 비해서 좋지 않음을 알 수 있는데 이는 해외시장 및 국내시장의 선행연구와 일치한다. 특히 최근 2 년간 액티브펀드의 성과는 패시브펀드에 비해 현저히 낮음을 알 수 있다.

<표 2>는 각 해마다 펀드의 수, 순자산액, 교체매매 비중, 보수, 보유 주식 수 및 현금 비율을 나타낸다. 교체매매 비중은 Paek and Ko(2015)와 유사하게 아래 식으로 계산하였다.

$$
\text { 교체매매 비중 } \mathrm{j,t}=\frac{\sum_{i} \mid \text { Holdings }_{i, j, t} \mid}{\left(T N A_{i, j, t-1}+T N A_{i, j, t}\right) / 2}
$$

이때, Holdings $s_{i, j, t}$ 는 $j$ 펀드가 $t$ 시점에 보유하고 있는 $i$ 주식의 시장가이며, 채권 등의 자산은 고려하지 않는다. Paek and $\mathrm{Ko}(2015)$ 의 방법과는 다르게 분모에는 순자산액 (TNA) 의 평균을 사용한다. 이는 주식보유 비중이 낮은 펀드의 교체매매 비중이 높게 추정 되는 것을 막아, 활발히 거래하는 정도를 더욱 잘 대변할 수 있도록 하기 위함이다. 전체 보수는 판매 보수, 운용 보수, 수탁 보수, 기타 보수를 모두 포함한다. 단 판매하는 방법에 따라서 상이한 보수가 부과되는 클래스 펀드와 모자 펀드의 경우, 운용 포트폴리오가 같은 펀드들의 보수를 순자산액으로 가중 평균하여 대표되는 보수를 산출하였다. 순자산액의 총합을 볼 때, 펀드의 규모가 2007년까지 급격하게 증가하다가 미국 발 신용위기로 인해 2008 2009년에 다소 감소함을 알 수 있다. 그 후 2010년도에 반등하였지만 최근에는 그 규모가 감소하는 추세에 있다. 전반적으로 펀드의 수가 증가하고 보수가 감소하는 추세를 통해 펀드 사이의 경쟁이 심해지고 있음을 짐작할 수 있으며, 개별 펀드가 보유하는 주식의 수는 꾸준히 증가하는 추세이다.

3 ) 액티브주식일반, 액티브주식섹터, 액티브주식배당, 액티브주식중소형, 액티브주식테마, 액티브주식 기타를 포함한다.

4) 최소 10 개 이상의 개별 펀드들이 존재하는 경우에만 특정 해의 수익률을 보고하였는데, 패시브펀드의 경우에는 2001년과 2002년의 표본 수가 충분하지 않았기 때문에 제외하였다. 
Mutual Fund Performance and Stock Market Anomalies

〈표 2〉국내 액티브펀드의 기초 통계량

이 표는 분석에 사용된 국내주식형 액티브펀드의 기초 통계값을 보고한다. 매년, 각 펀드별로 마지막에 관측된 순자산액을 이용하여 평균 순자산액과 순자산액의 총합을 계산하였다. 교체매매 비중은 월별 주식 보유 자료를 이용하여 아래의 식과 같이 계산하였다.

$$
\text { 교체매매 비중 } \mathrm{j,t}=\frac{\sum_{i} \mid \Delta \text { Holdings }_{i, j, t} \mid}{\left(T N A_{i, j, t-1}+T N A_{i, j, t}\right) / 2}
$$

이 때, Holdings $s_{i, j, t}$ 는 $j$ 펀드가 $t$ 시점에 보유하고 있는 $i$ 주식의 시장가이다. 산출된 월간 교체매매 비중을 이용해 연도별로 개별펀드의 평균 교체매매 비중을 계산하고, 최종적으로 연도별 교체 매매 비중을 계산하였다. 전체 보수는 판매 보수, 운용 보수, 수탁 보수, 기타 보수를 모두 포함한 값이다. 클래스 펀드와 모자 펀드의 경우, 운용 포트폴리오가 같은 펀드들의 보수를 순자산액으로 가중 평균하여 보수를 계산하였다. 한편, 현금 비율과 보유 주식수는 12 월을 기준으로 계산하였다.

\begin{tabular}{rrrrrrrrr}
\hline 연도 & 펀드 수 & $\begin{array}{c}\text { 순자산액 } \\
\text { (평균, } \\
\text { 백억원) }\end{array}$ & $\begin{array}{c}\text { 순자산액 } \\
\text { (총합, } \\
\text { 백억원) }\end{array}$ & $\begin{array}{c}\text { 교체매매 } \\
\text { 비중 } \\
(\%)\end{array}$ & $\begin{array}{c}\text { 전체 } \\
\text { 보수 } \\
(\%)\end{array}$ & $\begin{array}{c}\text { 보유 } \\
\text { 주식 수 } \\
\text { (평균) }\end{array}$ & $\begin{array}{c}\text { 보유 } \\
\text { 주식 수 } \\
\text { (중위값) }\end{array}$ & $\begin{array}{c}\text { 현금 } \\
\text { 비율 } \\
(\%)\end{array}$ \\
\hline 2001 & 181 & 3.52 & 637.00 & 12.47 & 1.83 & 48.09 & 40.0 & 7.20 \\
2002 & 208 & 3.45 & 718.11 & 10.88 & 1.81 & 45.31 & 38.0 & 1.74 \\
2003 & 200 & 3.13 & 626.79 & 9.62 & 1.83 & 50.10 & 39.5 & 1.56 \\
2004 & 177 & 2.07 & 366.22 & 11.73 & 1.83 & 50.24 & 41.0 & 4.21 \\
2005 & 191 & 8.49 & $1,620.70$ & 14.39 & 1.79 & 66.32 & 56.0 & 3.04 \\
2006 & 193 & 11.84 & $2,284.95$ & 11.92 & 1.76 & 51.95 & 53.5 & 1.52 \\
2007 & 225 & 21.57 & $4,854.03$ & 14.64 & 1.73 & 56.07 & 56.0 & 1.84 \\
2008 & 230 & 13.97 & $3,213.19$ & 13.29 & 1.72 & 53.69 & 55.0 & 3.51 \\
2009 & 237 & 14.45 & $3,425.19$ & 12.23 & 1.68 & 55.63 & 55.0 & 3.10 \\
2010 & 282 & 15.60 & $4,398.42$ & 11.78 & 1.64 & 55.60 & 55.0 & 2.47 \\
2011 & 311 & 13.19 & $4,100.53$ & 12.22 & 1.61 & 56.69 & 55.0 & 2.84 \\
2012 & 321 & 12.26 & $3,935.90$ & 10.62 & 1.57 & 54.59 & 56.0 & 2.34 \\
2013 & 317 & 11.05 & $3,501.73$ & 10.60 & 1.54 & 57.83 & 56.0 & 1.96 \\
2014 & 284 & 9.74 & $2,764.76$ & 11.06 & 1.54 & 63.55 & 60.0 & 2.55 \\
2015 & 327 & 11.29 & $3,691.34$ & 12.13 & 1.55 & 67.40 & 65.0 & 2.90 \\
2016 & 314 & 9.91 & $3,112.87$ & 9.21 & 1.56 & 63.69 & 60.0 & 3.44 \\
2017 & 300 & 10.23 & $3,068.06$ & 10.00 & 1.55 & 68.31 & 62.0 & 2.11 \\
\hline 평균 & 252.82 & 10.34 & $2,724.69$ & 11.69 & 1.68 & 56.77 & 53.12 & 2.84 \\
\hline
\end{tabular}

한편, 국내 주식의 수익률 및 기업특성 관련 변수들은 FnGuide사의 DataGuide Pro를 통해 확보하였다. 대상 주식은 유가증권시장에 상장된 보통 주식들이며 자본잠식 종목과 금융/유틸리티 업종은 분석 대상에서 제외하였다. 주식 수익률은 FnGuide에서 제공하는 배당을 고려한 총 수익률을 사용하였다. 분석의 결과가 극히 일부의 극단치에 의해 영향을 받지 않도록 하기 위해서, 상위 $0.001 \%$ 와 하위 $0.001 \%$ 의 수익률을 가지는 관측치를 분석 대상에서 제외하였다. 무위험 수익률에 대한 대용치로는 통화안정증권 364 일 물의 월별 수익률 자료를 사용하였다.

Carhart(1997)의 4요인 모형의 요인 포트폴리오를 구성하는 방법은 다음과 같다. 매년 6월 말, 우선 주식들을 그 해 6월 말 시장가치에 따라 50/50\%로 정렬하였다. 다음으로 
한국증권학회지 제49권 1호 (2020)

각 시장규모 그룹에 속한 주식에 대하여 지난 회계연도 장부가치 대 지난해 12 월 말의 시장가치의 비율에 따라 30/40/30\%의 세 그룹을 생성하였다. 이와 같은 과정에 의하여 생성된 총 6개의 포트폴리오의 가중평균 수익률을 계산한다. SMB(Small Minus Big)는 회 사규모가 작은 3 개와 큰 3 개 포트폴리오의 평균 수익률의 차이이며, HML(High Minus Low)는 장부가치 대 시장가치 비율이 높은 2 개와 낮은 2 개 포트폴리오의 평균 수익률의 차이로 정의한다. 모멘텀 요인도 가치 요인과 비슷하게 주식들을 $2 \times 3$ (기업규모 $\times$ 과거 수익률) 포트폴리오로 구축하여 계산하지만, 선행연구에 따라 매달 과거수익률에 기반한 포트폴리오를 재구성하였다. UMD(Up Minus Down)는 과거수익률이 높은 2개와 낮은 2개 포트폴리오의 평균 수익률의 차이이다.

\section{2 주요 변수}

\subsection{1 개별주식의 가격 오류(Mispricing) 측정}

가격 오류란 시장 가치와 내재 가치 간의 괴리를 의미한다. 현실적으로 특정 주식의 저평가 또는 고평가 여부를 판단하는 것은 매우 어려우며 이에 대하여 일치된 견해는 존재하지 않는다. 이러한 어려움에도 불구하고 본 연구에서는 최근 주식시장에서 보고된 수익률 이상 현상을 종합적으로 고려하여 주식의 고평가 및 저평가 여부를 판단하고자 한다. 이를 위해, Yoon et al.(2017) 등의 연구를 참고하여 <표 3>에서 정리된 총 10개의 이상현상을 종합 적으로 고려하여 특정 주식의 저평가 또는 고평가 여부를 판단한다. 이는 주식시장에서 발견된 이상현상의 일부는 가격 오류 때문에 발생하는 것으로 해석하는 Stambaugh et al.(2012)의 관점과 일치한다.

Yoon et al.(2017)의 연구는 가치주 효과, 모멘텀 효과, 신주발행 효과, 발생액 이상 효과, 총자산증가율 효과, 순영업자산 효과, 비유동성 효과, 수익성 효과, 이익수익률 효과, 저변동성 효과, 비체계적 위험 효과 등 11 가지의 이상현상을 고려하였다. 본 연구는 한국 자본시장 에서 문헌들이 공통적으로 중요하다고 보고하고 있는 기업규모 효과(Lee and Ok, 2015)를 포함하고, Yoon et al.(2017)이 고려한 이상현상들 중에서 유사성이 있는 효과들은 중복해서 고려할 필요가 적기 때문에 통합하였다. 예컨대 순영업자산 효과는 발생액 이상 효과와 구조적으로 유사하여 동시에 고려할 필요성이 낮다. 수익성 효과와 이익수익률 효과 역시 공통적으로 기업의 수익성과 주식 가격 사이의 관계를 살펴보므로 통합하였다. 대신 미국 주식형 펀드를 분석한 Jeon et al.(2017)이 고려하지 못한 유동성 효과가 국내 주식시장에서 중요하다고 판단하여 포함하였으며, 특히 거래량과 가격변화 사이의 관계로 측정되는 비 유동성과 거래활동 그 자체로 측정되는 유동성은 성격이 달라 분리될 필요가 있다고 판단 하여 Yoon et al.(2017)에서 고려하지 못한 거래회전율 효과를 추가적으로 고려하였다.

본 연구에서 고려하고 있는 이상현상 중 일부는 문헌에서 위험요인으로 간주되고 있다. 실증적으로 특수한 수익률 패턴을 야기하는 모든 이상현상들은 기본적으로 위험요인일 수도, 
Mutual Fund Performance and Stock Market Anomalies

가격오류로 인해 발생했을 수도 있다. 이러한 요인들은 이론적으로 위험요인으로 해석될 수 있을 때 비로소 위험요인으로 간주될 수 있다. 예컨대 CAPM은 시장요인이 위험요인 으로서 고려되어야 하는 이론적 근거를 설명한다. 반대로 이론적인 뒷받침이 없다면 위험 요인과 가격오류를 구별하기 어렵다. 문헌에서 고려되는 대표적 위험요인인 FamaFrench의 3요인 역시 시장요인을 제외하면 최초에는 이론적 배경 없이 기존에 잘 알려진 이상현상들을 설명하기 위한 소위 애드혹(Ad hoc) 위험요인에 불과했다. 물론 Zhang(2005)의 연구와 같이 점차 대표적인 위험요인들에 대해 이론적 근거가 마련되고 있는 것도 사실이다. 하지만 여전히 위험요인과 가격오류의 경계는 불분명하다고 할 것이다. 이러한 측면에서 Carhart의 4요인 역시 위험요인으로 볼 수도 있지만 다른 한편으로는 가격오류로 해석할 수도 있음을 고려하여 이 요인들을 이상현상으로 포함시켰다. 물론 이들은 위험요인으로 해석될 수 있으므로 기존에 알려진 위험요인들을 통제한 성과 역시 추가적으로 확인한다.

〈표 3〉이상현상 변수들의 설명

이 표는 본 논문에서 사용한 10 개의 이상현상들을 설명한다. 구체적으로, 각 이상현상 변수의 참고문헌과 변수의 설명을 나타낸다. 예상부호는 기존문헌에 기반한 변수와 수익률 사이의 예상 되는 관계를 의미하며, $(-)$ 는 해당 변수의 값이 높을수록 향후 수익률이 낮아야 함을 $(+)$ 는 해당 변수의 값이 높을수록 향후 수익률이 높음을 각각 의미한다.

\begin{tabular}{|c|c|c|c|}
\hline 이상현상 & 참고 문헌 & 변수 & 예상부호 \\
\hline 기업규모(ME) & Fama and French(2008) & 기업의 시가총액 & $(-)$ \\
\hline 가치(BM) & Fama and French(2008) & 장부가치 대 시장가치의 비율 & $(+)$ \\
\hline 모멘텀(MOM) & $\begin{array}{l}\text { Jegadeesh and Titman } \\
\text { (1993) }\end{array}$ & $\begin{array}{l}\text { 최근 } 1 \text { 달을 제외한 과거 } 12 \text { 개월 간의 } \\
\text { 수익률 }\end{array}$ & $(+)$ \\
\hline 투자(AG) & Cooper et al.(2008) & 총자산의 증가율 & $(-)$ \\
\hline 수익성(GPA) & Novy-Marx(2013) & 매출 총 이익 & $(+)$ \\
\hline 발생액(ACC) & Hribar and Collins(2002) & $\begin{array}{l}\text { 당기순이익과 영업활동으로 인한 현금 } \\
\text { 흐름의 차이 }\end{array}$ & $(-)$ \\
\hline 저변동성(TVOL) & Ang & 주식수익률의 변동성 & $(-)$ \\
\hline $\begin{array}{l}\text { 비체계적 위험 } \\
\text { (IVOL) }\end{array}$ & Ang et al.(2006) & $\begin{array}{l}\text { Fama-French 모형으로 설명되지 않 } \\
\text { 는 잔차의 변동성 }\end{array}$ & $(-)$ \\
\hline 거래회전율(TURN) & $\mathrm{Da}$ & 발행된 총 주식 중 거래가 된 비율 & $(-)$ \\
\hline 비유동성(ILLQ) & Amihud(2002) & 단위거래량 당 가격변화 & $(+)$ \\
\hline
\end{tabular}

또한 주가지수 수익률을 벤치마크로 사용하는 대다수의 액티브펀드들은 사실상 CAPM의 위험모형을 적용하는 것으로 볼 수 있다. 시장요인 외에 다른 위험요인이 실재한다고 하더라도 액티브펀드들은 다중요인 모형 하의 알파 대신 비시장 위험요인들에 대해 높은 베타를 취하는 식으로 벤치마크보다 높은 성과를 얻을 수 있기 때문이다. 즉, 주가지수 수익률과 비교하여 성과를 평가 받는 액티브펀드의 입장에서는 벤치마크 수익률보다 높은 기대수익률이 알파에 의해 발생한 것인지, 비시장 위험요인에 대한 추가적인 노출에 의한 것인지는 중요하지 않을 수 있다. 그렇다면 설사 위험요인이라고 하더라도 액티브펀드들은 이를 수익률 제고의 도구로 활용할 가능성이 높다. 
한국증권학회지 제49권 1호 (2020)

한편, 개별 주식의 가격 오류로부터 주식 수준의 지표를 추출할 수 있다. 본 연구에서는 미국 펀드 시장에서 Jeon et al.(2017)이 제안한 방식에 따라, 이상현상들을 종합하여 저평가된 주식들에는 높은 점수를 부여하고 고평가된 주식들에는 낮은 점수를 부여하는 A-Score 측정치(measure)를 식 (2)와 같이 계산하였다.

$$
\mathrm{A}-\mathrm{Score}_{\mathrm{i}, \mathrm{t}}=\sum_{k=1}^{10} \operatorname{Rank}_{i, k, t}
$$

이때, $\operatorname{Rank}_{i, k, t}$ 는 이상현상 $k$ 를 기준으로 $t$ 시점 주식의 순위를 의미한다. 이처럼 각 이상 현상마다 독립적으로 주식들을 10 분위로 정렬한 후 차례대로 1 부터 10 까지의 점수를 부여 한다. ${ }^{5)}$ 예상되는 수익률이 높은 (저평가된) 상위 $10 \%$ 의 주식은 +10 점을 획득하며, 2 분위에 속하는 주식은 +9 점, 그리고 하위 $10 \%$ 의 주식은 1 점을 획득하는 방식이다. 예를 들어, 특정 주식의 장부가치 대 시장가치 비율이 상위 $25 \%$ 속하여 상대적으로 예상되는 수익률이 높은 가치주로 분류되면 +8 점을 보유한다. 10 개의 특성에 대해 모두 같은 방식으로 점수를 계산한 후 합산을 통해 최종적인 $\mathrm{A}-\mathrm{Score}$ 를 산출한다. 특정 주식의 $\mathrm{A}-\mathrm{Score}$ 는 최대 100점에서 최소 10점 사이의 값을 가지게 된다.

Jeon et al.(2017)의 선행연구는 본 연구보다 더 많은 개수의 이상현상들을 고려했지만 유사한 성격의 이상현상들을 중복적으로 고려하였다. 즉, 15 개의 이상현상을 고려하였으나 성격이 중복되는 이상현상을 통합한다면 실제로는 Carhart 4요인 모형의 위험요인들, 자본 투자 효과, 신주발행 효과, 발생액 효과, 수익성 효과, 불확실성 효과의 6 개 그룹의 이상 현상을 고려하고 있다. 본 연구가 고려한 이상현상의 수는 10 가지로 이보다 절대적인 개수는 적지만 신주발행을 제외한 6 개 그룹의 이상현상을 모두 고려하고 있고, 이와 더불어 유동 성과 관련된 두 개의 이상현상을 추가적으로 고려했다는 점에서 의의가 있다.

이상현상들이 개별 주식의 저평가 또는 고평가 여부에 대한 잡음이 포함된 신호라면, 이들을 취합하여 정확성을 확보하기 위해서는 고려되는 이상현상들이 서로 독립적이어야 한다. 이들이 독립적이지 않다면 취합된 정보의 분산은 개별 이상현상에 의한 저평가 판단의 분산과 비교하여 큰 차이가 나지 않게 될 것이다. 즉, 저평가 여부를 판단할 때 유사한 성격의 이상현상들을 중복해서 고려하는 것은 바람직하지 않다. 유사한 성격을 가진 특성들은 동일한 주식에 대해 유사한 저평가 판정을 내릴 것이기 때문이다. 그러므로 성격이 다른 특성에 기반을 둔 이상현상들을 동시에 고려해야 한다. 성격이 상이한 이상현상들이 특정 주식을 공통적으로 저평가된 것으로 판단한다면 이는 보다 신뢰성 높은 저평가 판단 기준이 될 것이다. 이러한 측면에서 본 연구는 의도적으로 성격이 다른 이상현상들을 고려하여 AScore를 구성하고 이를 기반으로 저평가 여부를 판단하였다. 이는 단순 나열식으로 개별

5) 주식들을 3분위로 정렬하여 A-Score를 계산할 경우에도 본 연구의 결과와 유사한 결과가 도출됨을 확인하였다. 따라서 본 연구의 분석은 정렬 방식 변화에 강건하다고 판단된다. 
Mutual Fund Performance and Stock Market Anomalies

이상현상들의 존재 여부나 이상현상 사이의 상호관계를 살펴본 기존 연구들과 차별성을 갖는다.

\subsection{2 펀드 수준의 Investing Measure}

펀드들이 상대적으로 저평가된 주식을 많이 보유하고 있는지를 살펴보기 위하여, 펀드가 보유하고 있는 주식들의 평균 A-Score 순위를 계산하며, 이를 개별 펀드의 Investing measure로 정의하였다. 매달 주식들을 A-Score를 기준으로 10 분위로 나누면, 1(10)분위에는 고평가(저평가)된 주식들이 속하게 된다. 그 후에 보유 비중을 가중치로 하여 아래 식과 같이 Investing measure를 계산하였다.

$$
\text { Investing Measure }_{j, t}=\sum_{i=1}^{N_{j, t}} w_{i, j, t} \times \operatorname{Rank}_{i, t}
$$

이때, $w_{i, j, i}$ 는 $j$ 펀드가 $i$ 주식을 보유하고 있는 비중이고, $\operatorname{Rank}_{i, t}$ 는 저평가된 정도를 10 분위로 순위를 매긴 것이다. 이는 Grinblatt et al.(1995)가 사용한 Momentum Investing measure나 Ali et al.(2008)의 Accruals Investing measure와 비슷한 방식이다. Investing measure가 높은 펀드일수록 상대적으로 저평가된 주식을 많이 보유하고 있음을 의미한다.

이 방법의 장점은 다양한 포트폴리오나 이상현상에 대해서 쉽게 확장하여 적용할 수 있다는 점이다. 개별 펀드는 물론 전체 펀드의 포트폴리오를 하나로 합산하여 Investing measure를 계산할 수 있다. KOSPI와 같은 시장 포트폴리오에 대해서도 같은 방법으로 Investing measure를 계산할 수 있으므로 펀드가 벤치마크인 주요 지수에 비해서 얼마나 저평가된 주식을 보유하고 있는지를 확인할 수 있다. 또한 저평가된 정도의 순위를 계산할 때 필요에 따라서는 A-Score가 아닌 개별 이상현상을 사용할 수도 있다. 이를 통해 각 이상현상 별로 얼마나 저평가된 주식을 보유하고 있는지를 측정할 수 있다.

\section{4. 실증분석 결과}

\subsection{A-score에 따른 주식 포트폴리오의 수익률}

본 연구에서는 장기적으로 서로 다른 수익률을 창출한다고 알려진 10 개의 기업 특성변수 들을 사용한다. <표 4>는 본 연구에서 사용한 개별 기업 특성에 대한 이상현상이 국내 시장에서 존재하는지를 보고한다. 구체적으로, 매월 유가증권시장에 상장된 기업을 대상으로 개별 기업 특성변수에 대하여 3 분위 포트폴리오를 구성한 후 수익률이 높다고(낮다고) 알려진 포트폴리오를 매수(매도)한다. ${ }^{6)}$ 패널 A는 매수-매도 포트폴리오의 단순 수익률 차이를

6) 펀드가 보유하고 있는 종목으로 제한하여 <표 5>의 분석을 실시할 수 있다. 그러나, 표본기간동안 유가증권시장에 상장된 기업이 821 개이며, 펀드가 보유한 기업이 766 개로 큰 차이가 발생하지 않았기 때문에 펀드 편입 종목으로 제한한 분석은 실시하지 않았다. 
한국증권학회지 제49권 1호 (2020)

보고하며, 패널 B는 매수-매도 포트폴리오의 Carhart(1997) 4요인 알파를 나타낸다. 괄호 안의 값은 지연 시차 3의 Newey and West(1987) $t$-통계량이다. “EW"는 동일가중 수익률을 "VW"는 시장가치가중 수익률을 각각 의미한다.

〈표 4〉시장 이상현상 요인의 국내시장 유의성 검정

이 표는 개별 이상현상을 이용한 매수-매도 포트폴리오들의 월별 수익률을 보고한다. 〈표 3>의 방법에 따라서 계산된 각각의 이상현상 변수들로 매월 주식들을 정렬하여 3 분위 포트폴리오를 구성한다. 그 후, 각 이상현상 별로 수익률이 높다고 알려진 포트폴리오를 매수하고, 낮다고 알려진 포트폴리오를 매도하는 포트폴리오를 구성한다. 패널 $\mathrm{A}$ 는 이렇게 구성된 헤지 포트폴리오의 수익률이고, 패널 $\mathrm{B}$ 는 $\mathrm{MKT}, \mathrm{SMB}, \mathrm{HML}$ 그리고 $\mathrm{UMD}$ 을 포함하는 4요인 모형으로 추정된 알파 값이다. $\mathrm{EW}$ 는 동일가중 평균수익률을 나타내고, $\mathrm{VW}$ 는 시장가치가중 평균수익률을 나타낸다. 모든 수익률의 단위는 \%이다. 괄호 안의 값은 지연 시차 3의 Newey and West(1987) t-통계량이다. 표본기간은 2001년 7월부터 2017년 12월까지이다.

\begin{tabular}{|c|c|c|c|c|c|c|c|c|c|c|}
\hline & $\mathrm{ME}$ & $\mathrm{BM}$ & $\mathrm{MOM}$ & AG & GPA & ACC & TVOL & IVOL & TURN & ILLQ \\
\hline \multicolumn{11}{|c|}{ 패널 A: 수익률 } \\
\hline \multirow[t]{2}{*}{$\mathrm{EW}$} & 0.83 & 1.35 & 0.87 & 0.65 & 0.26 & 0.38 & 0.46 & 0.60 & 0.63 & 1.26 \\
\hline & $(2.24)$ & (6.38) & $(2.81)$ & $(4.40)$ & (1.22) & (3.23) & (1.69) & (2.33) & $(2.22)$ & (4.57) \\
\hline \multirow[t]{2}{*}{ VW } & 0.28 & 1.31 & 1.05 & 0.46 & -0.14 & 0.17 & 0.16 & 0.20 & 0.10 & 0.40 \\
\hline & $(0.63)$ & $(3.86)$ & $(2.56)$ & $(1.88)$ & $(-0.37)$ & $(0.53)$ & $(0.35)$ & $(0.49)$ & $(0.22)$ & (1.17) \\
\hline \multicolumn{11}{|c|}{ 패널 $\mathrm{B}: 4$ 요인 알파 } \\
\hline \multirow[t]{2}{*}{ EW } & & & & 0.74 & 0.49 & 0.45 & 0.36 & 0.45 & 0.44 & 1.30 \\
\hline & & & & $(4.46)$ & (2.73) & (3.69) & $(1.71)$ & (2.34) & (2.03) & (5.59) \\
\hline \multirow[t]{2}{*}{ VW } & & & & -0.00 & 0.76 & 0.65 & 0.91 & 0.61 & 0.60 & 0.06 \\
\hline & & & & $(-0.01)$ & (2.36) & (2.08) & $(2.21)$ & (1.57) & (1.59) & $(0.42)$ \\
\hline
\end{tabular}

동일가중 방식에서 대부분 이상현상의 매수-매도 스프레드 및 4 요인 알파가 양으로 유의하게 추정되었다. 그렇지만, 시장가치가중 방식에서는 양으로 유의하게 추정된 기업 특성 변수가 감소하는 양상을 보였다. 여전히 가치와 모멘텀에 대한 매수-매도 스프레드가 유의하게 추정되었으며, 수익성, 발생액, 저변동성에 대한 4 요인 모형의 알파도 통계적으로 유의한 양의 값으로 추정되었다. 종합적으로, 국내 주식시장에서의 이상현상은 대형주보다는 상대적으로 소형주에서 나타남을 짐작할 수 있는데 이는 미국시장의 선행연구와 일치한다. ${ }^{7)}$

특정 펀드의 수익률은 그 펀드를 구성하는 주식들의 시장가치가중 수익률이라는 측면에서 <표 3>의 기업특성들을 사용하여 구축하는 A-Score가 과연 개별 주식의 저평가 또는 고평가를 판단할 수 있을지에 대한 의문이 제기될 수 있다. 그러나, 시장가치가중 수익률에서도 대부분의 스프레드는 양의 값을 가지며 일부 스프레드는 통계적으로 유의하다는 측면과, 펀드 매니저들이 하나의 기업특성을 고려하기 보다는 여러 특성을 종합하여 종목을 선택할 가능성이 높다는 측면에서 이들 특성변수를 종합적으로 고려하는 방식이 유용할 수 있다.

7) Fama and French(2008)는 모멘텀효과, 순주식발행수효과, 그리고 발생액효과는 기업규모와 상관 없이 존재하지만 총자산증가율에 관한 이상현상은 소형주에 집중적으로 나타남을 보고하였다. 
〈표 5〉A-Score별 주식 수익률 및 특성

이 표는 A-Score로 주식을 정렬하여 구성한 포트폴리오의 수익률 및 특성을 보고한다. A-Score는 다음 식처럼 10 개의 이상현상을 종합하여 계산한다.

$$
\mathrm{A}-\text { Score }_{\mathrm{i}, \mathrm{t}}=\sum_{k=1}^{10} \operatorname{Rank}_{i, k, t}
$$

이 때, $\operatorname{Rank}_{i, k, t}$ 는 이상현상 $k$ 를 기준으로 $t$ 시점 i주식의 순위를 부여한 것으로, 가장 저(고)평가 된 주식이 10(1)점을 획득한다. 초과수익률은 동일가중으로 계산된 무위험이자율 대비 초과성과이며, 4요인 알파는 $\mathrm{MKT}, \mathrm{SMB}, \mathrm{HML}$ 그리고 $\mathrm{UMD}$ 을 포함하는 모형으로 추정된 알파이다. 괄호 안의 값은 지연 시차 3의 Newey and West(1987) t-통계량이다. 과거 수익률은 과거 12 개월 중에서 최근 한 달을 제외한 기간 동안의 수익률이다. 시장 베타는 최근 5년간 월별 수익률을 CAPM 모형으로 추정하였다. 변동성은 최근 3 개월 일간 수익률의 표준편차를 연율화한 값이다. 표본 기간은 2001년 7월부터 2017년 12월까지이다.

\begin{tabular}{|c|c|c|c|c|c|c|c|c|c|c|}
\hline & A-Score & $\begin{array}{c}\text { 초과 } \\
\text { 수익률 }(\%)\end{array}$ & $\begin{array}{l}4 \text { 요인 } \\
\alpha(\%)\end{array}$ & $\begin{array}{l}\text { 시가총액 } \\
\text { (백억원) }\end{array}$ & $\frac{\text { 장부가치 }}{\text { 시장가치 }}$ & $\begin{array}{c}\text { 과거 } \\
\text { 수익률 }(\%)\end{array}$ & $\begin{array}{l}\text { 시장 } \\
\text { 베타 }\end{array}$ & $\begin{array}{c}\text { 변동성 } \\
\text { (\%) }\end{array}$ & 비유동성 & $\begin{array}{c}\text { 거래 } \\
\text { 회전율 }(\%)\end{array}$ \\
\hline 1 & 34.01 & $\begin{array}{r}-0.50 \\
(-0.78)\end{array}$ & $\begin{array}{r}-1.41 \\
(-4.91)\end{array}$ & 129.06 & 0.97 & 1.25 & 1.10 & 64.56 & 0.51 & 3.15 \\
\hline 2 & 41.96 & $\begin{array}{r}0.48 \\
(0.78)\end{array}$ & $\begin{array}{r}-0.54 \\
(-2.14)\end{array}$ & 138.78 & 1.29 & 15.32 & 1.02 & 58.18 & 1.34 & 2.37 \\
\hline 3 & 46.36 & $\begin{array}{r}1.34 \\
(2.25)\end{array}$ & $\begin{array}{r}0.26 \\
(1.01)\end{array}$ & 149.18 & 1.45 & 22.54 & 0.99 & 55.27 & 3.75 & 2.09 \\
\hline 4 & 49.88 & $\begin{array}{r}1.29 \\
(2.49)\end{array}$ & $\begin{array}{r}0.32 \\
(1.74)\end{array}$ & 139.71 & 1.62 & 26.05 & 0.96 & 52.45 & 3.07 & 1.73 \\
\hline 5 & 53.20 & $\begin{array}{r}1.35 \\
(2.47)\end{array}$ & $\begin{array}{r}0.23 \\
(1.24)\end{array}$ & 126.03 & 1.80 & 26.89 & 0.93 & 49.44 & 4.49 & 1.45 \\
\hline 6 & 56.48 & $\begin{array}{r}1.83 \\
(3.41)\end{array}$ & $\begin{array}{r}0.54 \\
(2.99)\end{array}$ & 153.34 & 2.04 & 26.88 & 0.89 & 46.59 & 6.89 & 1.18 \\
\hline 7 & 60.00 & $\begin{array}{r}1.91 \\
(3.51)\end{array}$ & $\begin{array}{r}0.66 \\
(3.77)\end{array}$ & 101.65 & 2.23 & 22.97 & 0.86 & 42.65 & 11.92 & 0.83 \\
\hline 8 & 63.83 & $\begin{array}{r}2.15 \\
(4.08)\end{array}$ & $\begin{array}{r}0.89 \\
(5.44)\end{array}$ & 69.87 & 2.45 & 19.17 & 0.84 & 38.07 & 14.36 & 0.56 \\
\hline 9 & 68.31 & $\begin{array}{r}2.22 \\
(4.24)\end{array}$ & $\begin{array}{r}0.93 \\
(5.27)\end{array}$ & 16.39 & 2.67 & 18.36 & 0.80 & 33.83 & 16.20 & 0.37 \\
\hline 10 & 75.23 & $\begin{array}{r}2.27 \\
(4.71)\end{array}$ & $\begin{array}{r}1.06 \\
(6.06)\end{array}$ & 7.81 & 2.95 & 17.49 & 0.73 & 28.49 & 23.15 & 0.23 \\
\hline $10-1$ & & $\begin{array}{r}2.77 \\
(6.69) \\
\end{array}$ & $\begin{array}{r}2.46 \\
(6.74) \\
\end{array}$ & & & & & & & \\
\hline
\end{tabular}

위 질문에 대한 해답을 제시하기 위해서 <표 5>는 A-Score로 정렬된 10분위 포트폴리오의 수익률 및 특성을 나타낸다. 〈표 5>의 주요 결과는 다음과 같다. 첫째, A-Score가 높을수록 무위험자산 대비 초과수익률이 높게 측정되었다. A-Score가 가장 높은 $10 \%$ 의 주식을 매수하고 가장 낮은 $100 \%$ 의 주식을 매도하는 포트폴리오의 월 평균수익률은 $2.77 \%(t$-값=6.69)로 추정되었으며, Carhart(1997) 4요인 알파도 월 2.46\%(t-값=6.74)로 추정되었다. 또한, AScore에 따른 주식의 수익률 차이가 <표 4>에서 개별 기업특성을 고려한 수익률 차이보다 월등하게 크게 추정되었다. 이 결과들은 본 연구에서 사용한 A-Score는 주식의 가격오류를 포착하는 측정치가 될 수 있음을 시사한다. 관련하여, A-Score가 가장 낮은 2개의 포트폴리오의 4 
한국증권학회지 제49권 1호 (2020)

요인 알파는 음으로 유의하며 A-Score가 높은 $50 \%$ 의 4 요인 알파는 양으로 유의하게 추정 되었는데, 이를 통해 A-Score가 낮은(높은) 주식은 고평가(저평가) 되었음을 짐작할 수 있다. ${ }^{8)}$

둘째, A-Score로 구성된 주식 포트폴리오의 특성에 흥미로운 패턴이 관찰되었다. 우선, A-Score가 높은 주식의 베타는 상대적으로 낮게 추정되었는데, 이는 차입제약으로 인해 저베타 주식이 저평가되고 고베타 주식이 고평가되는 현상이 국내 시장에서도 존재함을 보고한 Kim and Hahn(2015)의 연구결과와 일치한다. CAPM 모형 하에서 접점포트폴리오보다 높은 기대수익률을 얻기 위해서는 차입을 통해 접점포트폴리오에 더 많은 투자 비중을 취해야 한다. 하지만 차입제약이 존재하는 경우에는 높은 레버리지를 취하는 것이 어려우므로 높은 기대수익률을 원하는 투자자들은 비효율적이더라도 고베타 자산의 비중을 늘려야 한다. 반대로 낮은 변동성을 원하는 투자자들은 차입제약과 상관없이 무위험 자산 또는 저위험 자산의 비중을 늘리는 방식으로 대응할 수 있다. 따라서 차입제약은 고베타 자산에 대한 수요를 비대칭적으로 증가시켜 고평가가 일어나게 할 수 있으며, 상대적으로 저베타 주식은 저평가될 수 있다. 또한, 저평가될수록 변동성이 낮게 추정되어 총위험도 낮은 것으로 나타났다. 한편, A-Score가 가장 낮은 $10 \%$ 주식의 과거수익률이 월등히 낮은 것으로 추정되었는데, 이는 2000년 이후에 국내 시장에서 모멘텀 현상이 뚜렷하게 나타남을 보고한 선행연구와 일치한다(Lee and Jang, 2015). 아울러 A-Score가 높은 주식일수록 유동성이 낮고 거래량이 작은 것으로 나타났다. 따라서 이들은 설사 실제로 저평가되어 있는 주식이라고 하더라도 액티브펀드의 투자제약으로 인해 포트폴리오 편입이 어려울 수 있다. 마지막으로, A-Score가 높은 주식은 소형주와 가치주로 드러났는데, 특히, A-Score가 가장 높은 $10 \%$ 주식의 시가 총액은 매우 낮게 추정되었다. 이는, 동일가중방식에서 이상현상이 두드러지게 관측된 <표 $4>$ 의 결과와 일치한다. 또한, 이는 펀드 매니저가 주식의 이상현상에 기반한 투자전략을 실행하 기가 쉽지 않음을 의미한다. 왜냐하면, KOSPI 200 지수 또는 KOSPI 지수가 대부분 주식형 펀드의 벤치마크로 사용되고 있다는 측면을 고려하면 펀드 매니저는 상대적으로 소형주에 대한 투자가 용이하지 않기 때문이다. 그러나, 규모효과와 가치효과를 모두 통제한 이후에도 $\mathrm{A}-\mathrm{Score}$ 가 높은 그룹의 4 요인 알파가 여전히 양으로 유의하다는 사실은 소형주, 가치주 이외에도 A-Score가 높은 그룹을 구성하는 다른 특성이 존재함을 의미한다. 따라서, 실제로 $\mathrm{A}-\mathrm{Score}$ 가 높은 주식에 투자하여 좋은 성과를 달성하는 펀드가 존재하는지에 대한 추가 분석이 필요하다.

8) 4 요인 모형을 통해 추정된 알파가 음의 값보다는 상대적으로 양의 값을 보이는 경향이 있는데, 이는 국내 주식시장에서 4 요인 모형이 모든 체계적위험을 대변하지 못하고 있음을 의미한다. 즉, 설명력이 더 우수한 모형을 사용하면 알파가 다소 감소될 수 있을 것으로 예상된다. 그럼에도 불구 하고 4 요인 모형이 펀드의 평가에서 가장 흔히 사용되므로 이후 펀드의 성과분석에서도 4 요인 모형을 사용한다. 다만, 이후의 분석에서 4 요인 모형의 알파가 대부분 음으로 추정되었다는 측면 에서 더 우수한 모형을 사용할 경우에도 국내 액티브펀드의 성과가 우월하지 못하다는 결론은 유지될 것으로 예상된다. 
Mutual Fund Performance and Stock Market Anomalies

\section{2 이상현상에 따른 주식형 펀드의 보유종목}

우선, 주식형 펀드가 상대적으로 저평가된 주식에 투자하고 있는지를 살펴본다. 이를 위해 식 (3)의 방법에 따라 개별 펀드의 Investing measure를 계산한다. 이 때, 이상현상을 종합적으로 고려하여 펀드의 Investing measure를 계산하기 위해서는 A-Score 10분위 순위를 사용하며, 개별 이상현상에 대해서 주식형 펀드가 어떤 포지션을 보유하는지를 살펴보기 위해서는 개별 특성변수 10 분위 순위를 사용한다. Investing measure가 높을수록 상대적으로 저평가된 주식을 보유하고 있음을 의미한다. 한편, 비교를 위해 KOSPI 지수, KOSPI 200, 그리고 표본 기간동안 존재하는 패시브펀드의 Investing measure를 같은 방식으로 계산하였다.

〈표 6〉 국내 액티브펀드의 포트폴리오 특성: Investing Measure 관점에서

이 표는 Investing measure의 관점에서 액티브펀드를 시장지수 및 패시브펀드와 비교한 결과를 나타낸다. Investing measure는 아래와 같이 계산된다.

$$
\text { Investing Measure }_{j, t}=\sum_{i=1}^{N_{j, t}} w_{i, j, t} \times \operatorname{Rank}_{i, t}
$$

이 때, $w_{i, j, i}$ 는 $j$ 펀드가 $i$ 주식을 보유하고 있는 비중이고, $\operatorname{Rank}_{i, t}$ 는 저평가된 정도를 10 분위로 순위를 매긴 것이다. $\operatorname{Rank}_{i, t}$ 는 1 부터 10 까지의 값을 가지며, A-Score나 개별 이상현상을 기준 으로 순위를 매긴다. Investing Measure 열은 Rank $k_{i, t}$ 를 정하는데 기준이 된 변수를 나타낸다. (A) (D)열은 각 포트폴리오의 Investing measure 값을 보고하며 펀드의 경우 소속된 펀드들을 하나의 포트폴리오로 종합하여 Investing measure를 계산하였다. (E) (G) 열은 액티브펀드의 포트폴리오와 다른 포트폴리오 간의 Investing Measure 차이를 보고하며, 괄호 안의 값은 $t$-통계량이다. 표본기간은 2001년 7월부터 2017년 12월까지이다.

\begin{tabular}{|c|c|c|c|c|c|c|c|c|c|}
\hline & (A) & (B) & (C) & (D) & \multicolumn{2}{|c|}{ (E) } & (F) & \multicolumn{2}{|c|}{ (G) } \\
\hline $\begin{array}{l}\text { Investing } \\
\text { Measure }\end{array}$ & $\begin{array}{l}\text { 액티브 } \\
\text { 펀드 }\end{array}$ & KOSPI & $\begin{array}{c}\text { KOSPI } \\
200\end{array}$ & $\begin{array}{c}\text { 패시브 } \\
\text { 펀드 }\end{array}$ & (A) & $-(\mathrm{B})$ & $(\mathrm{A})-(\mathrm{C})$ & (A) & $-(\mathrm{D})$ \\
\hline$\overline{\mathrm{A}-\text { Score }}$ & 4.35 & 4.44 & 4.48 & 4.47 & -0.08 & $(-8.17)$ & $-0.12(-12.28)$ & -0.11 & $(-10.47)$ \\
\hline $\mathrm{ME}$ & 1.36 & 1.17 & 1.44 & 1.13 & 0.19 & (14.26) & $-0.08 \quad(-7.97)$ & 0.23 & (19.99) \\
\hline $\mathrm{BM}$ & 3.15 & 3.06 & 3.22 & 2.99 & 0.10 & $(6.46)$ & $-0.05 \quad(-3.38)$ & 0.17 & (10.42) \\
\hline $\mathrm{MOM}$ & 6.47 & 6.17 & 6.18 & 6.18 & 0.32 & (12.43) & 0.31 & 0.29 & (10.75) \\
\hline AG & 4.22 & 4.16 & 4.24 & 4.15 & 0.06 & (3.09) & $-0.02 \quad(-1.03)$ & 0.07 & $(4.09)$ \\
\hline GPA & 7.16 & 7.27 & 7.15 & 7.35 & -0.11 & $(-7.29)$ & $(0.99)$ & -0.19 & $(-11.98)$ \\
\hline $\mathrm{ACC}$ & 6.61 & 6.84 & 6.70 & 6.90 & -0.22 & $(-15.15)$ & $-0.08 \quad(-6.51)$ & -0.29 & $(-19.01)$ \\
\hline TVOL & 6.67 & 6.81 & 6.69 & 6.91 & -0.15 & $(-9.20)$ & $-0.02 \quad(-1.15)$ & -0.24 & $(-14.35)$ \\
\hline IVOL & 7.40 & 7.61 & 7.40 & 7.74 & -0.21 & $(-12.32)$ & $-0.01 \quad(-0.43)$ & -0.34 & $(-19.57)$ \\
\hline TURN & 6.04 & 6.39 & 6.34 & 6.33 & -0.36 & $(-34.47)$ & $-0.30(-26.53)$ & -0.30 & $(-26.95)$ \\
\hline ILLQ & 1.46 & 1.24 & 1.55 & 1.17 & 0.21 & $(12.05)$ & $-0.09 \quad(-6.29)$ & 0.29 & $(18.29)$ \\
\hline
\end{tabular}

<표 6>의 (A) (D)열은 액티브펀드, 주요 시장지수, 그리고 패시브펀드의 Investing measure를 나타낸다. (E) (G)열은 액티브펀드의 포트폴리오와 다른 포트폴리오의 Investing measure 차이를 보고하며, 괄호 안의 값은 $t$-통계량이다. <표 6 >의 주요 결과는 다음과 같다. 첫째, 액티브펀드 전체의 Investing measure는 4.35로 추정되었으며 이는 주요 벤치마크나 패시브펀드의 Investing measure와 미세한 차이를 보였지만 일관되게 낮게 추정되었다. 즉, 전체적으로 액티브펀드는 벤치마크에 비해 저평가된 주식을 많이 보유하고 있지 않은 
한국증권학회지 제49권 1호 (2020)

것으로 나타났으며 이는 액티브펀드의 우월하지 못한 성과와 관련이 있는 것으로 짐작된다. 둘째, 개별 기업특성에 기반한 펀드의 Investing measure는 벤치마크나 패시브펀드와 유사하게 측정되었는데 이는, 평균적으로 국내 액티브펀드가 주식시장의 이상현상에 기반한 투자를 하고 있지 않음을 의미한다. 셋째, Investing measure의 차이가 크지는 않지만 액티브펀드는 벤치마크에 비해 과거승자주에 투자하는 경향이 있는 것으로 나타났는데 이는 평균적으로 펀드매니저들이 모멘텀투자를 하고 있음을 의미한다. 한편, 액티브펀드는 상대적으로 고평가된 발생액이 높은 주식, 변동성이 높은 주식, 그리고 회전율이 높은 주식에 투자하고 있는 것으로 나타났지만, 벤치마크의 Investing measure와 큰 차이를 나타내지는 않는다. 결과적으로, 액티브펀드는 벤치마크에 비해 저평가된 주식을 상대적으로 많이 보유하고 있다고 해석하기는 힘들다.

한편, 평균적으로 액티브펀드가 벤치마크에 비해 저평가된 주식에 투자하지 않더라도 일부의 액티브펀드는 이상현상에 기반하여 저평가된 종목을 보유할 가능성이 있다. 이를 확인하기 위해 펀드들을 Investing measure를 기준으로 5 분위 그룹으로 나눈 후, 각 그룹 펀드들의 A-Score에 따른 투자비중을 산출하였으며 <표 7>의 Panel A는 그 결과를 나타낸다. Q1(Q5)은 Investing measure가 가장 낮은(높은) 그룹을 의미하며, D1(D10)은 A-Score가 가장 낮은(높은) 그룹을 의미한다. 한편, 패널 $\mathrm{B}$ 는 액티브펀드 전체(Fund)와 KOSPI 지수의 A-Score별 투자비중 및 액티브펀드와 KOSPI, 그리고 Investing measure가 높은(낮은) 그룹과 KOSPI 간의 투자 비중 차이를 보고한다.

〈표 7〉A-Score별 투자 비중

패널 $\mathrm{A}$ 는 펀드들을 Investing measure를 기준으로 5 분위 그룹으로 나눈 후, 각 그룹 펀드들의 $\mathrm{A}-\mathrm{Score}$ 별 투자비중을 나타낸다. 패널 B는 액티브펀드 전체(Fund)와 KOSPI 지수의 A-Score별 투자비중 및 액티브펀드와 KOSPI, 그리고 Investing measure가 높은(낮은) 그룹과 KOSPI 간의 투자 비중 차이를 보고한다. 표본기간은 2001년 7월부터 2017년 12월까지이다.

\begin{tabular}{|c|c|c|c|c|c|c|c|c|c|c|}
\hline & \multicolumn{10}{|c|}{ 주식 A-Score } \\
\hline & D1 & D2 & D3 & D4 & D5 & D6 & D7 & D8 & D9 & D10 \\
\hline \multicolumn{11}{|c|}{ 패널 A: Investing Measure 기준으로 정렬된 펀드 그룹 } \\
\hline Q1 & $14.7 \%$ & $18.4 \%$ & $17.2 \%$ & $13.6 \%$ & $12.0 \%$ & $13.6 \%$ & $7.4 \%$ & $2.7 \%$ & $0.4 \%$ & $0.1 \%$ \\
\hline Q2 & $11.0 \%$ & $15.6 \%$ & $16.6 \%$ & $14.0 \%$ & $13.2 \%$ & $16.1 \%$ & $9.2 \%$ & $3.7 \%$ & $0.7 \%$ & $0.2 \%$ \\
\hline Q3 & $9.1 \%$ & $14.2 \%$ & $16.3 \%$ & $14.4 \%$ & $14.0 \%$ & $16.9 \%$ & $9.8 \%$ & $4.6 \%$ & $0.7 \%$ & $0.1 \%$ \\
\hline Q4 & $7.8 \%$ & $12.5 \%$ & $15.4 \%$ & $15.0 \%$ & $14.9 \%$ & $17.9 \%$ & $10.5 \%$ & $5.1 \%$ & $0.8 \%$ & $0.2 \%$ \\
\hline Q5 & $5.1 \%$ & $8.9 \%$ & $11.7 \%$ & $13.1 \%$ & $14.6 \%$ & $18.2 \%$ & $13.7 \%$ & $8.6 \%$ & $3.9 \%$ & $2.2 \%$ \\
\hline Q5-Q1 & $-9.6 \%$ & $-9.5 \%$ & $-5.6 \%$ & $-0.5 \%$ & $2.6 \%$ & $4.6 \%$ & $6.3 \%$ & $5.9 \%$ & $3.4 \%$ & $2.1 \%$ \\
\hline \multicolumn{11}{|c|}{ 래널 B: 다른 포트폴리오와의 비교 } \\
\hline Fund & $9.3 \%$ & $13.9 \%$ & $15.4 \%$ & $14.1 \%$ & $13.8 \%$ & $16.5 \%$ & $10.1 \%$ & $4.9 \%$ & $1.3 \%$ & $0.6 \%$ \\
\hline KOSPI & $10.3 \%$ & $12.2 \%$ & $13.7 \%$ & $13.7 \%$ & $13.5 \%$ & $17.1 \%$ & $10.9 \%$ & $6.1 \%$ & $1.5 \%$ & $0.7 \%$ \\
\hline Fund-KOSPI & $-1.0 \%$ & $1.7 \%$ & $1.8 \%$ & $0.4 \%$ & $0.3 \%$ & $-0.6 \%$ & $-0.8 \%$ & $-1.2 \%$ & $-0.2 \%$ & $-0.2 \%$ \\
\hline Q1-KOSPI & $4.8 \%$ & $6.2 \%$ & $3.4 \%$ & $-0.5 \%$ & $-1.9 \%$ & $-4.2 \%$ & $-3.8 \%$ & $-3.1 \%$ & $-0.5 \%$ & $-0.1 \%$ \\
\hline Q5-KOSPI & $-5.2 \%$ & $-3.3 \%$ & $-2.0 \%$ & $-0.6 \%$ & $1.1 \%$ & $1.1 \%$ & $2.8 \%$ & $2.5 \%$ & $2.4 \%$ & $1.5 \%$ \\
\hline
\end{tabular}


Panel A을 통해 Investing measure가 가장 높은 그룹은 그 수치가 가장 낮은 그룹에 비해 고평가된 주식은 상대적으로 적게 보유하고 있으며, 저평가된 주식은 상대적으로 많이 보유하고 있음을 알 수 있다. 예를 들어, Q5가 Q1에 비해 가장 고평가된 주식(D1)을 9.6\%p 적게 보유하고 있으며 가장 저평가된 주식(D10)은 $2.1 \%$ p 많이 보유하고 있는 것으로 드러났다. Panel B에서 액티브펀드 전체와 KOSPI 지수를 비교하였는데 A-Score별 투자 비중에 큰 차이가 존재하지 않았으며 이는 <표 6>의 결과와 일치한다. 한편, Q5 그룹은 KOSPI에 비해 저평가된 주식의 보유비중은 높으며 고평가된 주식의 보유비중은 낮은 것으로 추정 되었는데, 이는 Q5 그룹에 속한 액티브펀드들은 상대적으로 저평가된 주식을 보유하고 있음을 의미한다. 그러나, Q1 Q4 그룹의 펀드들은 KOSPI에 비해 저평가된 주식의 보유 비중이 낮은 것으로 추정되었다. 결론적으로, 대부분의 액티브펀드는 저평가된 주식의 보유 비중이 벤치마크에 비해 낮지만, 일부 펀드는 저평가된 주식의 투자비중이 높고 고평가된 주식의 투자비중이 낮은 것으로 추정되었다.

\subsection{Investing Measure에 따른 액티브펀드의 성과}

본 절에서는 Investing measure에 따른 액티브펀드의 성과를 분석한다. 이를 위해, 매 달마다 액티브펀드들을 Investing measure를 기준으로 5 분위로 나눈 후 순자산액 가중평균 월 수익률을 계산하였다. 〈표 8>은 Investing measure로 분류한 5개 그룹의 Investing measure, 초과 수익률, CAPM 알파, Carhart(1997)의 4요인 모형 알파, 그리고 샤프비율을 각각 나타낸다. 패널 $\mathrm{A}$ 는 비용 공제 이전의 성과를 보고하며 패널 $\mathrm{B}$ 는 보수를 차감한 성과를 보고한다. 초과수익률은 무위험이자율 대비 초과성과를 의미하며 샤프 비율은 평균 무위험 이자율 대비 초과수익률을 전체 기간 동안에서 추정된 변동성으로 나누어 계산한다. 괄호 안의 값은 지연 시차 3 의 Newey and West(1987) $t$-통계량이다.

비용 공제 이전의 수익률을 분석한 Panel A의 주요 결과는 다음과 같다. 첫째, 액티브펀드의 평균 초과수익률은 월 $0.85 \%$ 로 추정되었지만, 시장위험을 통제한 CAPM 알파는 월 $0.04 \%$ 로 추정되었다. 이는 액티브펀드의 성과가 시장보다 우월하지 못함을 의미하며 이전 분석의 결과와도 일치한다. 또한, 4 요인모형의 알파는 월 $-0.03 \%$ 로 추정되어 액티브펀드의 저성과가 다시 한번 확인되었다. 둘째, Investing measure는 액티브펀드의 성과 차이를 설명할 수 있는 지표임이 확인되었다. Investing measure가 증가할수록 모든 성과지표들은 향상되었으며 특히, Investing measure가 가장 높은 펀드 그룹은 그 지표가 가장 낮은 그룹에 비해 CAPM 알파는 월 $0.33 \%$ (연 3.96\%), 그리고 4요인 알파는 월 $0.27 \%$ (연 3.24\%) 높게 추정 되었으며 이는 통계적으로 유의하다. Investing measure가 미래 펀드 수익률의 횡단면을 설명할 수 있는 관측치임을 발견한 것은 본 연구의 가장 중요한 결과이며 <표 9>에서 이에 대한 강건성 검증을 실시한다. 셋째, Investing measure가 가장 높은 Q5 그룹의 CAPM 알파는 월 $0.20 \%$ ( $t$-값=2.14)로 추정되었다. 액티브펀드의 벤치마크가 대부분 KOSPI 지수나 KOSPI 200 지수라는 측면을 고려하면 Q5 그룹은 시장보다 우월한 성과를 달성하는 것으로 
한국증권학회지 제49권 1호 (2020)

해석할 수 있다. 그러나, 4 요인 알파는 월 $0.08 \%$ ( $t$-값=0.90)으로 추정되어 기업규모요인, 가치요인, 모멘텀요인을 통제한 초과수익률은 존재하지 않는 것으로 나타났다. <표 8>의 Panel B는 비용 공제 이후의 수익률을 분석한 결과를 나타낸다. 전반적으로, 펀드의 성과는 악화되었지만, Q5-Q1의 수익률은 비용 공제 이전과 유사하게 추정되었다. 즉, 향후 펀드 성과에 대한 Investing measure의 예측력이 재확인되었다. ${ }^{9}$

〈표 8〉Investing Measure에 따른 펀드의 성과

이 표는 Investing measure에 따른 펀드들의 성과를 보고한다. Q1 Q5는 매월 액티브펀드들을 Investing measure를 기준으로 5 분위로 나눈 개별 포트폴리오를 의미하며, 이 때 수익률은 순자산액을 가중평균하여 계산하였다. 초과수익률은 무위험이자율 대비 초과성과를 의미한다. 모든 수익률은 월간 수익률이며, 괄호 안의 값은 지연 시차 3 의 Newey and West(1987) $t$-통계량이다. 샤프 비율은 평균 무위험 이자율 대비 초과수익률을 전체 기간 동안에서 추정된 변동성으로 나누어 계산한다. 패널 $\mathrm{A}$ 는 비용 공제 이전의 성과를 보고하며, 패널 $\mathrm{B}$ 는 보수를 차감한 성과를 각각 나타낸다. 표본기간은 2001년 7월부터 2017년 12월까지이다.

\begin{tabular}{lcrrrr}
\hline & $\begin{array}{c}\text { Investing } \\
\text { Measure }\end{array}$ & $\begin{array}{c}\text { 초과수익률 } \\
(\%)\end{array}$ & $\begin{array}{c}\text { CAPM 알파 } \\
(\%)\end{array}$ & 4요인 알파 (\%) & 샤프 비율 \\
\hline 패널 A: 비용 공제 전 & & & & \\
\hline Q1 & 3.75 & $0.73(1.59)$ & $-0.13(-1.30)$ & $-0.20(-2.00)$ & 0.44 \\
Q2 & 4.11 & $0.75(1.70)$ & $-0.09(-1.03)$ & $-0.13(-1.52)$ & 0.47 \\
Q3 & 4.27 & $0.84(1.94)$ & $0.02(0.16)$ & $-0.04(-0.46)$ & 0.53 \\
Q4 & 4.44 & $0.87(2.05)$ & $0.06(0.73)$ & $0.01(0.09)$ & 0.57 \\
Q5 & 5.20 & $0.92(2.33)$ & $0.20(2.14)$ & $0.08(0.90)$ & 0.66 \\
Q5-Q1 & & $0.19(1.52)$ & $0.33(2.97)$ & $0.27(2.64)$ & 0.36 \\
액티브펀드 전체 & 4.39 & $0.85(1.99)$ & $0.04(0.50)$ & $-0.03(-0.45)$ & 0.55 \\
\hline 패널 B: 비용 공제 후 & & & & \\
\hline Q1 & 3.75 & $0.62(1.34)$ & $-0.24(-2.36)$ & $-0.31(-3.24)$ & 0.37 \\
Q2 & 4.11 & $0.62(1.39)$ & $-0.22(-2.68)$ & $-0.27(-3.29)$ & 0.38 \\
Q3 & 4.27 & $0.73(1.66)$ & $-0.11(-1.10)$ & $-0.16(-1.64)$ & 0.45 \\
Q4 & 4.44 & $0.74(1.71)$ & $-0.08(-0.88)$ & $-0.14(-1.54)$ & 0.47 \\
Q5 & 5.20 & $0.81(2.00)$ & $0.07(0.79)$ & $-0.04(-0.46)$ & 0.57 \\
Q5-Q1 & & $0.19(1.57)$ & $0.31(2.78)$ & $0.27(2.61)$ & 0.37 \\
액티브펀드 전체 & 4.39 & $0.73(1.69)$ & $-0.09(-1.23)$ & $-0.16(-2.13)$ & 0.47 \\
\hline
\end{tabular}

펀드의 수익률을 예측한다고 알려진 변수들이 존재하는 상황에서도 Investing measure의 예측력이 있는지를 살펴보기 위해서 아래의 회귀분석을 실시하였다.

9) 전체 표본기간인 2001년 7월부터 2017년 12월까지의 기간을 국내 주식시장이 상대적으로 호황 이었던 2001년 7월부터 2009년 12월까지의 기간과 상대적으로 불황이었던 2010년 1월부터 2017년 12월까지의 기간으로 나누어 분석하였을 때, 기간과 상관없이 A-Score가 높은 펀드들의 성과가 그렇지 않은 펀드들에 비해 높게 나타남을 확인하였다. 


$$
\begin{aligned}
\text { alpha }_{i, t}= & \beta_{1} \text { InvestingMeasure }_{i, t-1}+\beta_{2} \log (T N A)_{i, t-1}+\beta_{3}[\log (T N A)]_{i, t-1}^{2} \\
& +\beta_{4} \log (A G E+1)_{i, t-1}+\beta_{5} \text { Expenses }_{i, t-1}+\beta_{6} \text { Turnover }_{i, t-1} \\
& +\beta_{7} \text { alpha }_{i, t-1}+\beta_{8} \text { flow }_{i, t-1}+\beta_{9} \text { TE }_{i, t-1}+\beta_{10} R_{i, t-1}^{2}+\text { YearDmmies }+\varepsilon_{i, t}
\end{aligned}
$$

$a l p h a$ 는 펀드의 성과로 무위험 이자율 대비 초과수익률과 Carhart(1997)의 4요인 모형으로 추정된 알파를 사용하였다. $T N A$ 는 펀드의 순자산액을 의미하며 $A G E$ 는 펀드 설정일로부터 경과된 시간으로 측정된 펀드의 나이를 의미한다. Expenses 는 펀드의 총보수를 의미하여, Turnover 는 교체매매를 나타낸다. Past return 은 펀드의 전월 수익률이며, flow 는 현금흐름으로 전월 유입된 현금의 양을 순자산액으로 나눈 값으로 다음 식과 같이 계산하였다.

$$
\text { flow }_{i, t}=\frac{T N A_{i, t}-T N A_{i, t-1} \times \operatorname{Ret}_{i, t}}{T N A_{i, t-1}}
$$

$T E$ 는 추적오차를 의미하며 벤치마크 대비 수익률의 표준 편차로 최근 3개월의 일간 수익률로 계산하였다. 이때 벤치마크는 FnGuide에서 개별 펀드마다 지정한 벤치마크 인덱스를 사용하였다. $R^{2}$ 는 전월의 일간 초과수익률을 Carhart(1997)의 4요인으로 회귀분석하여 추정된 결정계수이며, 이는 $R^{2}$ 가 펀드 매니저의 종목선택능력을 포착한다는 Amihud and Goyenko(2013)의 결과를 반영한 것이다. 한편, 모든 회귀 분석 모형은 시간 고정효과 (time fixed effect)를 고려하여 시간 더미(dummy)를 포함하였다.

\section{〈표 9〉펀드 성과의 회귀 분석}

이 표는 펀드의 성과에 대한 회귀분석 결과를 나타낸다. 종속변수는 펀드의 월간 성과로, 무위험 이자율 대비 초과수익률과 Carhart(1997)의 4요인 알파를 사용하였다. TNA는 순자산액(단위: 원)이며, 나이(age)는 펀드 설정일로부터 경과된 시간(단위: 연)이다. 보수(expenses)는 월간 총 보수이며, 교체매매(turnover)는 식 (1)에 따라 계산한다. 과거수익률(past return)은 해당 펀드의 전월 수익률이고, 현금흐름(flow)은 전월 유입된 현금의 양을 순자산액으로 나눈 값이다. 추적오차(TE)는 벤치마크 대비 수익률의 표준 편차로 최근 3개월의 일별 수익률로 계산한다. 이 때 벤치마크는 FnGuide에서 개별 펀드마다 지정한 벤치마크 인덱스를 사용한다. $\mathrm{R}^{2}$ 는 4 요인 모형의 결정계수 값으로, 매월 전달의 일간 수익률로 계산한다. 패널 $\mathrm{A}$ 는 비용 공제 이전의 성과를 보고하며, 패널 $\mathrm{B}$ 는 보수를 차감한 성과를 보고한다. 가독성을 위해 모든 계수는 100 배하여 보고한다. 또한 조정결정계수 $\left(A d j R^{2}\right)$ 와 사용된 관측치의 개수를 보고한다. 모든 회귀 분석 모형은 시간 고정효과(time fixed effect)를 고려하여 시간 더미(dummy)를 포함하였다. 괄호 안의 값은 기업에 대해 클러스터 된 표준오차(robust standard error clustered by fund)를 이용해 계산된 $t$-통계량이다. 표본기간은 2001년 7월부터 2017년 12월까지이다.

\begin{tabular}{lcccccc}
\hline & \multicolumn{3}{c}{ 초과수익률 } & \multicolumn{3}{c}{ 4요인 알파 } \\
\hline 패널 A: 비용 공제 전 & & & & \\
\hline Investing Measure & 0.196 & 0.217 & 0.219 & 0.118 & 0.125 & 0.126 \\
& $(7.20)$ & $(8.94)$ & $(9.27)$ & $(4.97)$ & $(5.71)$ & $(5.77)$ \\
$\ln$ (TNA) & & 0.242 & 0.214 & & 0.090 & 0.095 \\
& & $(1.74)$ & $(1.53)$ & & $(0.69)$ & $(0.73)$ \\
\hline
\end{tabular}


한국증권학회지 제49권 1호 (2020)

〈표 9〉펀드 성과의 회귀 분석(계속)

\begin{tabular}{|c|c|c|c|c|c|c|}
\hline & \multicolumn{3}{|c|}{ 초과수익률 } & \multicolumn{3}{|c|}{ 4요인 알파 } \\
\hline$[\ln (\mathrm{TNA})]^{2}$ & & $\begin{array}{l}-0.005 \\
(-1.81)\end{array}$ & $\begin{array}{l}-0.005 \\
(-1.60)\end{array}$ & & $\begin{array}{l}-0.002 \\
(-0.74)\end{array}$ & $\begin{array}{l}-0.002 \\
(-0.78)\end{array}$ \\
\hline $\ln ($ Age +1$)$ & & $\begin{array}{l}-0.113 \\
(-6.24)\end{array}$ & $\begin{array}{l}-0.117 \\
(-6.48)\end{array}$ & & $\begin{array}{l}-0.114 \\
(-6.74)\end{array}$ & $\begin{array}{l}-0.111 \\
(-6.56)\end{array}$ \\
\hline Expenses & & $\begin{array}{l}-0.159 \\
(-0.58)\end{array}$ & $\begin{array}{l}-0.196 \\
(-0.60)\end{array}$ & & $\begin{array}{l}0.108 \\
(0.36)\end{array}$ & $\begin{array}{l}0.099 \\
(0.33)\end{array}$ \\
\hline Turnover & & $\begin{array}{l}0.171 \\
(0.89)\end{array}$ & $\begin{array}{l}0.194 \\
(1.03)\end{array}$ & & $\begin{array}{l}0.112 \\
(0.87)\end{array}$ & $\begin{array}{l}0.117 \\
(0.91)\end{array}$ \\
\hline Past return & & $\begin{array}{r}7.226 \\
(10.37)\end{array}$ & $\begin{array}{r}7.129 \\
(10.39)\end{array}$ & & $\begin{array}{l}4.225 \\
(7.24)\end{array}$ & $\begin{array}{l}4.182 \\
(7.22)\end{array}$ \\
\hline Flow & & $\begin{array}{l}0.015 \\
(0.36)\end{array}$ & $\begin{array}{l}0.016 \\
(0.37)\end{array}$ & & $\begin{array}{l}0.015 \\
(0.36)\end{array}$ & $\begin{array}{l}0.015 \\
(0.36)\end{array}$ \\
\hline $\mathrm{TE}$ & & & $\begin{array}{r}-29.777 \\
(-3.15)\end{array}$ & & & $\begin{array}{l}-3.465 \\
(-0.40)\end{array}$ \\
\hline $\mathrm{R}^{2}$ & & & $\begin{array}{r}-0.536 \\
(-2.39) \\
\end{array}$ & & & $\begin{array}{r}-0.216 \\
(-1.42) \\
\end{array}$ \\
\hline 시간 더미 & 포함 & 포함 & 포함 & 포함 & 포함 & 포함 \\
\hline $\operatorname{Adj} R^{2}$ & 0.892 & 0.898 & 0.898 & 0.219 & 0.232 & 0.232 \\
\hline $\mathrm{N}$ & 44,284 & 38,986 & 38,986 & 44,207 & 38,970 & 38,970 \\
\hline 패널 $\mathrm{B}$ : 비용 공제 후 & & & & & & \\
\hline Investing Measure & $\begin{array}{l}0.209 \\
(7.66)\end{array}$ & $\begin{array}{l}0.216 \\
(8.94)\end{array}$ & $\begin{array}{l}0.218 \\
(9.27)\end{array}$ & $\begin{array}{l}0.127 \\
(5.37)\end{array}$ & $\begin{array}{l}0.124 \\
(5.71)\end{array}$ & $\begin{array}{l}0.126 \\
(5.77)\end{array}$ \\
\hline $\ln (\mathrm{TNA})$ & & $\begin{array}{l}0.240 \\
(1.73)\end{array}$ & $\begin{array}{l}0.211 \\
(1.51)\end{array}$ & & $\begin{array}{l}0.088 \\
(0.67)\end{array}$ & $\begin{array}{c}0.092 \\
(0.71)\end{array}$ \\
\hline$[\ln (\mathrm{TNA})]^{2}$ & & $\begin{array}{l}-0.005 \\
(-1.80)\end{array}$ & $\begin{array}{l}-0.005 \\
(-1.59)\end{array}$ & & $\begin{array}{l}-0.002 \\
(-0.72)\end{array}$ & $\begin{array}{l}-0.002 \\
(-0.76)\end{array}$ \\
\hline $\ln ($ Age +1$)$ & & $\begin{array}{l}-0.113 \\
(-6.23)\end{array}$ & $\begin{array}{l}-0.117 \\
(-6.48)\end{array}$ & & $\begin{array}{l}-0.114 \\
(-6.73)\end{array}$ & $\begin{array}{l}-0.110 \\
(-6.56)\end{array}$ \\
\hline Expenses & & $\begin{array}{l}-1.115 \\
(-3.38)\end{array}$ & $\begin{array}{l}-1.122 \\
(-3.45)\end{array}$ & & $\begin{array}{l}-0.847 \\
(-2.80)\end{array}$ & $\begin{array}{l}-0.857 \\
(-2.84)\end{array}$ \\
\hline Turnover & & $\begin{array}{r}0.171 \\
(0.89)\end{array}$ & $\begin{array}{l}0.195 \\
(1.04)\end{array}$ & & $\begin{array}{l}0.112 \\
(0.87)\end{array}$ & $\begin{array}{l}0.117 \\
(0.92)\end{array}$ \\
\hline Past return & & $\begin{array}{r}7.230 \\
(10.38)\end{array}$ & $\begin{array}{r}7.133 \\
(10.40)\end{array}$ & & $\begin{array}{l}4.225 \\
(7.24)\end{array}$ & $\begin{array}{l}4.182 \\
(7.22)\end{array}$ \\
\hline Flow & & $\begin{array}{l}0.015 \\
(0.36)\end{array}$ & $\begin{array}{l}0.016 \\
(0.37)\end{array}$ & & $\begin{array}{l}0.015 \\
(0.36)\end{array}$ & $\begin{array}{l}0.015 \\
(0.36)\end{array}$ \\
\hline $\mathrm{TE}$ & & & $\begin{array}{r}-29.712 \\
(-3.15)\end{array}$ & & & $\begin{array}{l}-3.404 \\
(-0.39)\end{array}$ \\
\hline $\mathrm{R}^{2}$ & & & $\begin{array}{l}-0.534 \\
(-2.39)\end{array}$ & & & $\begin{array}{l}-0.215 \\
(-1.42)\end{array}$ \\
\hline 시간 더미 & 포함 & 포함 & 포함 & 포함 & 포함 & 포함 \\
\hline $\operatorname{Adj} R^{2}$ & 0.896 & 0.898 & 0.898 & 0.225 & 0.232 & 0.232 \\
\hline $\mathrm{N}$ & 40,173 & 38,986 & 38,986 & 40,134 & 38,970 & 38,970 \\
\hline
\end{tabular}


<표 9>의 Panel A는 비용 공제 이전의 결과를 Panel B는 비용 공제 이후의 회귀분석 결과를 각각 나타낸다. 가독성을 위해 모든 계수는 100 배하여 보고하였으며, 조정결정계수 $\left(\operatorname{Adj} R^{2}\right)$ 와 사용된 관측치의 개수를 표시하였다. 괄호 안의 값은 기업에 대해 클러스터 된 표준오차(robust standard error clustered by fund)를 이용해 계산된 $t$-통계량이다. <표 9>에 의하면 종속변수 및 통제변수의 포함여부에 상관없이 Investing measure의 값은 양으로 유의하게 추정되었다. 즉, 본 연구에서 제시된 Investing measure의 미래 펀드 수익률에 대한 예측력이 다시 한번 확인되었다. 한편, Investing measure의 예측력은 경제적으로 유의하다. 예를 들어, 초과수익률이 종속변수로 사용되는 경우에 Investing measure의 계수는 0.196 0.219의 값으로 추정되었는데 이는 Investing measure가 한 단위 증가할수록 향후 펀드의 수익률이 월 0.196 0.219\% 증가함을 의미한다. 결과적으로, 〈표 8> 및 〈표 9>의 결과는 상대적으로 저평가된 주식에 투자하는 펀드일수록 향후 수익률이 높음을 의미하므로 Investing measure는 액티브펀드의 성과향상에 기여하는 지표임이 확인되었다.

\subsection{Investing Measure의 특성}

본 절에서는 펀드의 미래 성과에 대한 예측력을 보유하고 있는 Investing measure의 특성에 대해서 살펴보고자 한다. 구체적으로, Investing measure에 따른 펀드의 여러 가지 특성과 Investing measure의 지속성에 대해서 살펴본다.

<표 10>은 Investing measure에 따른 펀드의 여러 가지 특성을 나타낸다. 구체적으로, Investing measure를 기준으로 매달 표본 펀드들을 5 분위 그룹으로 나누어 평균 특성을 계산한 후 전체 기간에 대한 평균을 산출하였다. <표 9>에서 사용된 특성변수 이외에 보유 주식수(\# of stocks), 시장베타(market beta), 현금보유(cash holding)를 추가하였다. 시장 베타(market beta)는 매 월 펀드의 전 달 일간 수익률을 이용하여 추정하였으며, 현금보유는 현금 보유량을 순자산액으로 나눈 값이다.

<표 10>의 주요 결과는 다음과 같다. 첫째, 상대적으로 저평가된 주식에 많이 투자하는 펀드일수록 시장베타가 낮게 추정되었다. 이는 차입제약으로 인해 상대적으로 저평가된 주식의 시장베타가 낮음을 보고한 <표 5>의 결과와 일치한다. 둘째, Investing measure가 높은 펀드일수록 교체매매 비중이 낮게 측정되었으며, Investing measure가 가장 높은 Q5 그룹의 교체매매 비중이 다른 그룹에 비해 특히 낮게 측정되었다. 셋째, Q1과 Q5 그룹의 추적오차는 높고 $\mathrm{R}^{2}$ 는 낮게 추정되었는데, 이는 저평가 또는 고평가된 종목에 투자하는 펀드일수록 벤치마크와의 괴리가 큰 액티브성(activeness)이 강한 펀드라는 직관과 일치 한다. 넷째, 액티브성이 큰 펀드일수록 순자산액 및 펀드로의 현금유입이 높게 측정되었으며, 펀드의 나이는 상대적으로 낮게 측정되었다. 결과적으로 A-Score가 높은 Q5 그룹은 다른 펀드들보다 시장베타가 1 과 차이가 크며, 추적오차 역시 가장 크다. 다시 말해, A-Score를 기준으로 저평가된 종목을 많이 보유하려는 펀드들은 상대적으로 벤치마크에서 더 많이 벗어날 수 밖에 없고, 저평가되어 있는 종목들을 더 적극적으로 활용하기 위해서는 투자 제약이 완화될 필요가 있다. 
한국증권학회지 제49권 1호 (2020)

〈표 10〉Investing Measure에 따른 펀드 특성

이 표는 Investing measure에 따른 펀드의 특성을 보고한다. Investing measure는 식 (3)에 따라 A-Score를 기준으로 계산된 펀드 수준의 저평가 정도이다. Investing measure를 기준으로 매달 펀드들을 5 분위 그룹으로 나누어 평균 특성을 계산한 후 전체 기간에 대해 평균한다. 순자산액 (TNA)의 단위는 백억원이고, 보수(expenses)는 연간 총 보수이다. 교체매매(turnover)는 식 (1)에 따라 계산하였다. 나이(age)는 펀드 설정일로부터 경과된 시간이다. 현금흐름(flow)은 전 연도 유입된 현금의 양을 순자산액으로 나눈 값이다. 보유주식수(\# of stocks)는 보유하고 있는 종목 중에서 A-Score값을 가지는 주식들의 개수이다. 시장베타(market beta)는 매달 펀드의 전 달 일간 수익률로 계산하였다. 현금보유(cash holding)는 현금 보유량을 순자산액으로 나눈 값이다. 추적오차(TE)는 벤치마크 대비 수익률의 표준 편차로 최근 3개월의 일별 수익률로 계산하며, 연율화(annualize)하였다. 이 때 벤치마크는 FnGuide에서 개별 펀드마다 지정한 벤치마크 인덱스를 사용하였다. $\mathrm{R}^{2}$ 는 4 요인 모형의 결정계수 값으로, 매월 전월의 일간 수익률로 계산하였다. 표본 기간은 2001년 7월부터 2017년 12월까지이다.

\begin{tabular}{lrrrrr}
\hline & \multicolumn{1}{c}{ Q1 } & Q2 & Q3 & Q4 & \multicolumn{1}{c}{ Q5 } \\
\hline Investing Measure & 3.75 & 4.11 & 4.27 & 4.44 & 5.02 \\
TNA(백억원) & 11.00 & 8.77 & 8.88 & 8.70 & 12.02 \\
Expenses(\%/연) & 1.65 & 1.68 & 1.69 & 1.70 & 1.69 \\
Turnover(\%) & 12.22 & 11.56 & 11.44 & 11.23 & 9.58 \\
Age(연) & 4.48 & 5.54 & 5.85 & 5.50 & 4.64 \\
Flow(\%/연) & 24.21 & 0.19 & 0.71 & 1.01 & 10.52 \\
\# of stocks & 46.11 & 54.66 & 58.41 & 52.75 & 50.12 \\
Market beta & 0.95 & 0.94 & 0.93 & 0.91 & 0.80 \\
Cash holding(\%) & 2.22 & 2.36 & 2.47 & 2.40 & 2.47 \\
TE(\%/연) & 7.20 & 5.87 & 5.70 & 5.82 & 7.26 \\
$\mathrm{R}^{2}(\%)$ & 88.45 & 92.00 & 92.61 & 92.15 & 88.46 \\
\hline
\end{tabular}

〈표 11〉Investing Measure의 전이 행렬

이 표는 Investing measure를 통해 5 분위로 나누어진 펀드 그룹들 간의 전이행렬을 나타낸다. 매년 7월에 Investing measure를 이용하여 펀드들을 5 개의 그룹으로 나눈다. 이후 $\mathrm{t}$ 년과 $\mathrm{t}+1$ $\sim \mathrm{t}+5$ 년 사이의 전이 확률을 계산하였다. 패널 $\mathrm{A}$ 는 저평가된 포트폴리오를 보유하는 $\mathrm{Q} 5$ 그룹에 대한 전이 행렬이며, 패널 $\mathrm{B}$ 는 고평가된 포트폴리오를 보유하는 $\mathrm{Q} 1$ 그룹의 전이 행렬을 각각 나타낸다. 표본기간은 2001년 7월부터 2017년 7월까지이다.

\begin{tabular}{llllll}
\hline & $\mathrm{Q} 1$ & $\mathrm{Q} 2$ & $\mathrm{Q} 3$ & $\mathrm{Q} 4$ & $\mathrm{Q} 5$ \\
\hline 패널 A: Q5 & & & & & \\
\hline Year $t+1$ & 0.05 & 0.08 & 0.08 & 0.19 & 0.60 \\
Year $t+2$ & 0.10 & 0.10 & 0.09 & 0.17 & 0.54 \\
Year $t+3$ & 0.06 & 0.14 & 0.12 & 0.17 & 0.50 \\
Year $t+4$ & 0.09 & 0.16 & 0.15 & 0.14 & 0.46 \\
Year $t+5$ & 0.12 & 0.13 & 0.15 & 0.16 & 0.43 \\
\hline 패널 B: Q1 & & & & & \\
\hline Year $t+1$ & 0.38 & 0.21 & 0.20 & 0.14 & 0.07 \\
Year $t+2$ & 0.35 & 0.21 & 0.23 & 0.15 & 0.06 \\
Year $t+3$ & 0.29 & 0.23 & 0.24 & 0.17 & 0.06 \\
Year $t+4$ & 0.24 & 0.18 & 0.25 & 0.26 & 0.07 \\
Year $t+5$ & 0.22 & 0.27 & 0.23 & 0.21 & 0.07 \\
\hline
\end{tabular}


Investing measure에 따른 펀드 매니저의 투자결정에 지속성이 존재하는지의 여부를 살펴보기 위해서 <표 11>은 Investing measure가 가장 높은 그룹(Q5)과 가장 낮은 그룹 (Q1)의 전이 행렬을 나타낸다. 구체적으로, 매년 7월에 Investing measure를 이용하여 펀드들을 5 개의 그룹으로 나눈 후, $\mathrm{t}$ 년과 $\mathrm{t}+1 \sim \mathrm{t}+5$ 년 사이의 전이 확률을 계산하였다. 패널 $\mathrm{A}$ 는 가장 저평가된 포트폴리오를 보유하는 Q5 그룹에 대한 전이 행렬이며, 패널 $\mathrm{B}$ 는 가장 고평가된 포트폴리오를 보유하는 Q1 그룹의 전이 행렬을 각각 나타낸다. Q1 그룹에 비해서 Q5 그룹의 지속성이 상대적으로 높게 측정되었다. Q5 그룹에 속한 펀드가 1년 후에 Q5 그룹에 머무를 확률이 $60 \%$ 로 측정되었으며, 5년 후에도 같은 그룹에 포함될 확률이 $43 \%$ 로 측정되었다. 이와 반대로, Q1 그룹에 속한 펀드가 1년 후에 같은 그룹에 포함될 확률은 $38 \%, 5$ 년 후에도 같은 그룹에 머무를 확률은 $22 \%$ 로 측정되었다. 결과적으로, Investing measure의 지속성이 확인되었으며 특히, 상대적으로 저평가된 주식에 많이 투자하는 펀드일수록 지속성이 높은 것으로 나타났다. 이는, 상대적으로 저평가된 주식에 투자하고 있는 펀드 매니저의 투자 전략에 지속성이 존재함을 의미한다.

\section{5. 결론}

본 연구에서는 주식시장에서 보고된 이상현상에 기반하여 국내 주식형펀드의 운용스타일 및 저성과의 원인을 분석하였다. 국내시장에서 서로 다른 수익률을 야기하는 새로운 기업 특성변수들이 활발하게 보고되고 있으며, 주식형 펀드는 결국 주식으로 구성된 포트폴리오라는 측면에서 주식형 펀드의 성과를 이 관점에서 살펴보는 연구는 액티브펀드의 성과에 대한 이해에 큰 도움이 될 것으로 판단하였다. 구체적으로, 주식 수익률의 차이를 야기하는 10 개 변수를 통해 개별 주식의 저평가 또는 고평가 여부를 측정하였으며 이를 토대로 개별 펀 드가 상대적으로 저평가된 주식을 보유하고 있는지를 살펴보았다.

실증분석 결과는 전반적으로 국내 액티브펀드 매니저들이 주식시장의 이상현상을 종합 적으로 고려한 팩터(factor) 투자전략을 구사하고 있지 않다는 것을 보여주었다. 이는 국내 주식시장에서 아직까지 팩터의 유용성에 대해 잘 정립된 연구결과가 부족했기 때문에 야기될 수 있다. 그럼에도 불구하고, 실제로 일부 액티브펀드는 벤치마크에 비해 지속적으로 저 평가된 종목을 보유하고 있으며 상대적으로 우수한 성과를 달성하고 있음을 확인하였다. 일반적으로 펀드 매니저들은 특정 펀드를 운용함에 있어 일정 비중이상의 벤치마크 종목 편입 의무, 추적오차 한도 등과 같은 제약을 받는다. 저평가된 종목이 대체로 소형주이며, 낮은 유동성을 보이는 것을 감안할 때 본 연구의 결과는 펀드매니저가 당면한 제약이 액티브펀드의 성과에 부정적인 영향을 미쳤을 가능성이 있음을 시사한다. 
한국증권학회지 제49권 1호 (2020)

\section{References}

Akbas, F., W. J. Armstrong, S. Sorescu, and A. Subrahmanyam, 2015, Smart Money, Dumb Money, and Capital Market Anomalies, Journal of Financial Economics, Vol. 118, pp. 355-382.

Ali, A., X. Chen, T. Yao, and T. Yu, 2008, Do Mutual Funds Profit from the Accruals Anomaly?, Journal of Accounting Research, Vol. 46, pp. 1-26.

Ali, A., X. Chen, T. Yao, and T. Yu, 2014, Mutual Fund Competition and Profiting from the Post Earnings Announcement Drift, Working Paper, University of Texas at Dallas.

Amihud, Y., 2002, Illiquidity and Stock Returns: Cross-Section and Time-Series Effects, Journal of Financial Markets, Vol. 5, pp. 31-56.

Amihud, Y., and R. Goyenko, 2013, Mutual Fund's R ${ }^{2}$ as Predictor of Performance, Review of Financial Studies, Vol. 26, pp. 667-694.

Ang, A., R. J. Hodrick, Y. H. Xing, and X. Y. Zhang, 2006, The Cross-Section of Volatility and Expected Returns, Journal of Finance, Vol. 61, pp. 259-299.

Banz, R. W., 1981, The Relationship between Return and Market Value of Common Stocks, Journal of Financial Economics, Vol. 9, pp. 3-18.

Busse, J. A., A. Goyal, and S. Wahal, 2013, Investing in a Global World, Review of Finance, Vol. 18, pp. 561-590.

Carhart, M. M., 1997, On Persistence in Mutual Fund Performance, Journal of Finance, Vol. 52, pp. 57-82.

Chan, L. K. C., H. L. Chen, and J. Lakonishok, 2002, On Mutual Fund Investment Styles, Review of Financial Studies, Vol. 15, pp. 1407-1437.

Chen, C. K., 2015, Aggregate Mutual Fund Flows and Cross-Sectional Anomalies, Working Paper, University of Houston.

Cooper, M. J., H. Gulen, and M. J. Schill, 2008, Asset Growth and the Cross-Section of Stock Returns, Journal of Finance, Vol. 63, pp. 1609-1651.

Cremers, K. J. M., and A. Petajisto, 2009, How Active is Your Fund Manager? A New Measure that Predicts Performance, Review of Financial Studies, Vol. 22, pp. 33293365.

Datar, V. T., N. Y. Naik, and R. Radcliffe, 1998, Liquidity and Stock Returns: An Alternative Test, Journal of Financial Markets, Vol. 1, pp. 203-219.

Edelen, R. M., O. S. Ince, and G. B. Kadlec, 2016, Institutional Investors and Stock Return Anomalies, Journal of Financial Economics, Vol. 119, pp. 472-488.

Eom, Y. S., 2013, Momentum Profits and Firm Size, Korean Journal of Financial Studies, Vol. 
42 (5), pp. 901-927.

Fama, E. F., and K. R. French, 1993, Common Risk Factors in the Returns on Stocks and Bonds, Journal of Financial Economics, Vol. 33, pp. 3-56.

Fama, E. F., and K. R. French, 2006, Profitability, Investment and Average Returns, Journal of Financial Economics, Vol. 82, pp. 491-518.

Fama, E. F., and K. R. French, 2008, Dissecting Anomalies, Journal of Finance, Vol. 63, pp. $1653-1678$.

French, K. R., 2008, Presidential Address: The Cost of Active Investing, Journal of Finance, Vol. 63, pp. 1537-1573.

Grinblatt, M., and S. Titman, 1989, Mutual Fund Performance: An Analysis of Quarterly Portfolio Holdings, Journal of Business, Vol. 62, pp. 393-416.

Grinblatt, M., S. Titman, and R. Wermers, 1995, Momentum Investment Strategies, Portfolio Performance, and Herding: A Study of Mutual Fund Behavior, American Economic Review, Vo. 85, pp. 1088-1105.

Ha, Y. J., 2014, Equity Fund Fees and Performance, Korean Journal of Business Research, Vol. 29 (4), pp. 289-308.

Hribar, P., and D. W. Collins, 2002, Errors in Estimating Accruals: Implications for Empirical Research, Journal of Accounting Research, Vol. 40, pp. 105-134.

Jegadeesh, N., and S. Titman, 1993, Returns to Buying Winners and Selling Losers: Implications for Stock Market Efficiency, Journal of Finance, Vol. 48, pp. 65-91.

Jensen, M. C., 1968, The Performance of Mutual Funds in the Period 1945-1964, Journal of Finance, Vol. 23, pp. 389-416.

Jeon, H., J. Kang, and C. Lee, 2017, Do the Actively Managed Mutual Funds Exploit the Stock Market Mispricing?, Working Paper, Korea Advanced Institute of Science and Technology.

Kacperczyk, M., C. Sialm, and L. Zheng, 2005, On the Industry Concentration of Actively Managed Equity Mutual Funds, Journal of Finance, Vol. 60, pp. 1983-2011.

Kim, C. H., and C. J. Lee, 2018, Market Liquidity and Momentum Profits : Evidence from the Korean Stock Market, Korean Journal of Futures and Options, Vol. 26 (4), pp. 497524.

Kim, D. C., 2004, Structural Shifts of Market Betas and Common Risk Factors in Korean Stock Returns, Korean Journal of Financial Studies, Vol. 33 (4), pp. 95-134.

Kim, M. K., J. S. Jung, and T. S. Kim, 2018, Dissecting Profitability Premium in Korean Stock Markets, Korean Journal of Financial Management, Vol. 35 (4), pp. 69-108.

Kim, T. H., and J. H. Hahn, 2015, On the Relationshiop between Leverage Constraints and 
한국증권학회지 제49권 1호 (2020)

Stock Returns: An Empirical Investigation using the "Betting against Beta" Factor in Korea, Asian Review of Financial Research, Vol. 28 (4), pp. 589-624.

Ko, B. C., and J. W. Kim, 2007, Does the Accrual Anomaly Reflect a Risk Factor? The Case of the Korean Stock Market, Korean Journal of Financial Studies, Vol. 36 (3), pp. 425-461.

Ko, B. C., and J. W. Kim, 2009, Accrual Anomaly and Arbitrage Trading Opportunity, Korean Journal of Financial Studies, Vol. 38 (1), pp. 77-105.

Ko, B. C., and J. W. Kim, 2014, Low Volatility Anomaly and its Profitability in Korean Stock Markets, Korean Journal of Financial Studies, Vol. 43 (3), pp. 573-603.

Ko, K. S., 2011, A Survey of Mutual Fund Studies: Implications for Korean Markets, Asian Review of Financial Research, Vol. 24, pp. 275-365.

Ko, K. S., 2014, The Effect of Management and Sales Fees on Equity Fund Returns, Korean Journal of Financial Management, Vol. 31 (4), pp. 129-150.

Lee, C. J., and H. L. Jeon, 2012, On the Investigation of Investment Style Consistency in Korean Equity Funds, Korean Journal of Financial Management, Vol. 29 (3), pp. 83106.

Lee, C. J., and J. W. Jang, 2015, Size, Book-to-Market, and Momentum Effects Across Economic States: Evidence from the Korean Stock Market, Korean Journal of Financial Management, Vol. 32 (2), pp. 201-234.

Lee, M. K., and K. Y. Ok, 2015, Market Anomalies and Multifactor Models: Comparison between the FF Model and the CNZ model, Korean Journal of Financial Studies, Vol. 44 (5), pp. 855-885.

Newey, W. K., and K. D. West, 1987, A Simple, Positive Semi-Definite, Heteroskedasticity and Autocorrelation Consistent Covariance Matrix, Econometrica, Vol. 55, pp. 703708.

Novy-Marx, R., 2013, The Other Side of Value: The Gross Profitability Premium, Journal of Financial Economics, Vol. 108, pp. 1-28.

Paek, M. Y., and K. S. Ko, 2015, Do Frequent Tradings Add Value? Profitability of Equity Fund Investors, Korean Journal of Futures and Options, Vol. 23 (1), pp. 41-72.

Piotroski, J. D., 2000, Value Investing: The Use of Historical Financial Statement Information to Separate Winners from Losers, Journal of Accounting Research, Vol. 38, pp. $1-41$.

Rosenberg, B., K. Reid, and R. Lanstein, 1985, Efficient Capital Markets: II, Persuasive Evidence of Market Inefficiency, Vol. 11, pp. 9-16.

Sloan, R. G., 1996, Do Stock Prices Fully Reflect Information in Accruals and Cash Flows 
Mutual Fund Performance and Stock Market Anomalies

about Future Earnings?, Accounting Review, Vol. 71, pp. 289-315.

Stambaugh, R. F., and Y. Yuan, 2016, Mispricing Factors, Review of Financial Studies, Vol. 30, pp. 1270-1315.

Stambaugh, R. F., J. Yu, and Y. Yuan, 2012, The Short of it: Investor Sentiment and Anomalies, Journal of Financial Economics, Vol. 104, pp. 288-302.

Stattman, D., 1980, Book Values and Stock Returns, The Chicago MBA: A Journal of Selected Papers, Vol. 4, pp. 25-45.

Tice, S., and L. Zhou, 2011, Mutual Funds and Stock Fundamentals, Working Paper, Tulane University.

Titman, S., K. C. J. Wei, and F. X. Xie, 2004, Capital Investments and Stock Returns, Journal of Financial and Quantitative Analysis, Vol. 39, pp. 677-700.

Wermers, R., 2000, Mutual Fund Performance: An Empirical Decomposition into Stock-Picking Talent, Style, Transactions Costs, and Expenses, Journal of Finance, Vol. 55, pp. 1655-1695.

Yoo, S. I., and D. C. Kim, 2012, Style, Performance, Market Timing of Equity Mutual Funds in Korea, Asian Review of Financial Research, Vol. 25 (3), pp. 409-450.

Yoon, B. H., K. W. Sohn, and W. S. Liu, 2017, Smart Beta Strategy in Korean Stock Market, Korean Journal of Futures and Options, Vol. 25 (2), pp. 279-304.

Yun, S. Y., B. I. Ku, Y. H. Eom, and J. H. Hahn, 2009, The Cross-Section of Stock Returns in Korea: An Empirical Investigation, Asian Review of Financial Research, Vol. 22 (1), pp. 1-44.

Zhang, L., 2005, The Value Premium, Journal of Finance, Vol. 60, pp. 67-103. 